\title{
Organic Matter Distributions in Oil Shales of the Green River Formation, Piceance Basin
}

\author{
By
}

Justin E. Birdwell, Ronald C. Johnson, and Tracey J. Mercier

U.S. Geological Survey, Central Energy Resources Science Center, Denver, CO USA 


\section{Critical elements of this talk:}

- There was abundant clay (primarily illite) entering Lake Uinta throughout its history.

- We propose that most of the organic matter reached the bottom of the lake attached to fine-grained particles - mainly clay.

- Clay is largely missing from the hypersaline interval deposited in the central part of the lake today, due to disassociation to form authigenic feldspars and dawsonite.

- The clay probably sourced largely from Cretaceous marine rocks that were exposed on uplifts surrounding the lake. 


\section{Critical elements continued:}

- This hypothesis may solve the problem of how lipid-rich Type 1 organic matter derived from algal material with a density of no greater than 1.05 could have settled through the hypersaline lower layer in Lake Uinta, which probably had a density of between 1.1 to 1.2. 
For the mostly laminated Mahogany zone, there is a very strong linear correlation between thickness and total kerogen in place as measured by barrels per acre, with the majority of data points falling between the two black lines.

The data points to the right of the trend are near the basin margins and probably include coarser clastic sediments.

(Data from Piceance Oil Shale

Database; see Johnson et al., 2010 for details)

\section{\#USGS}

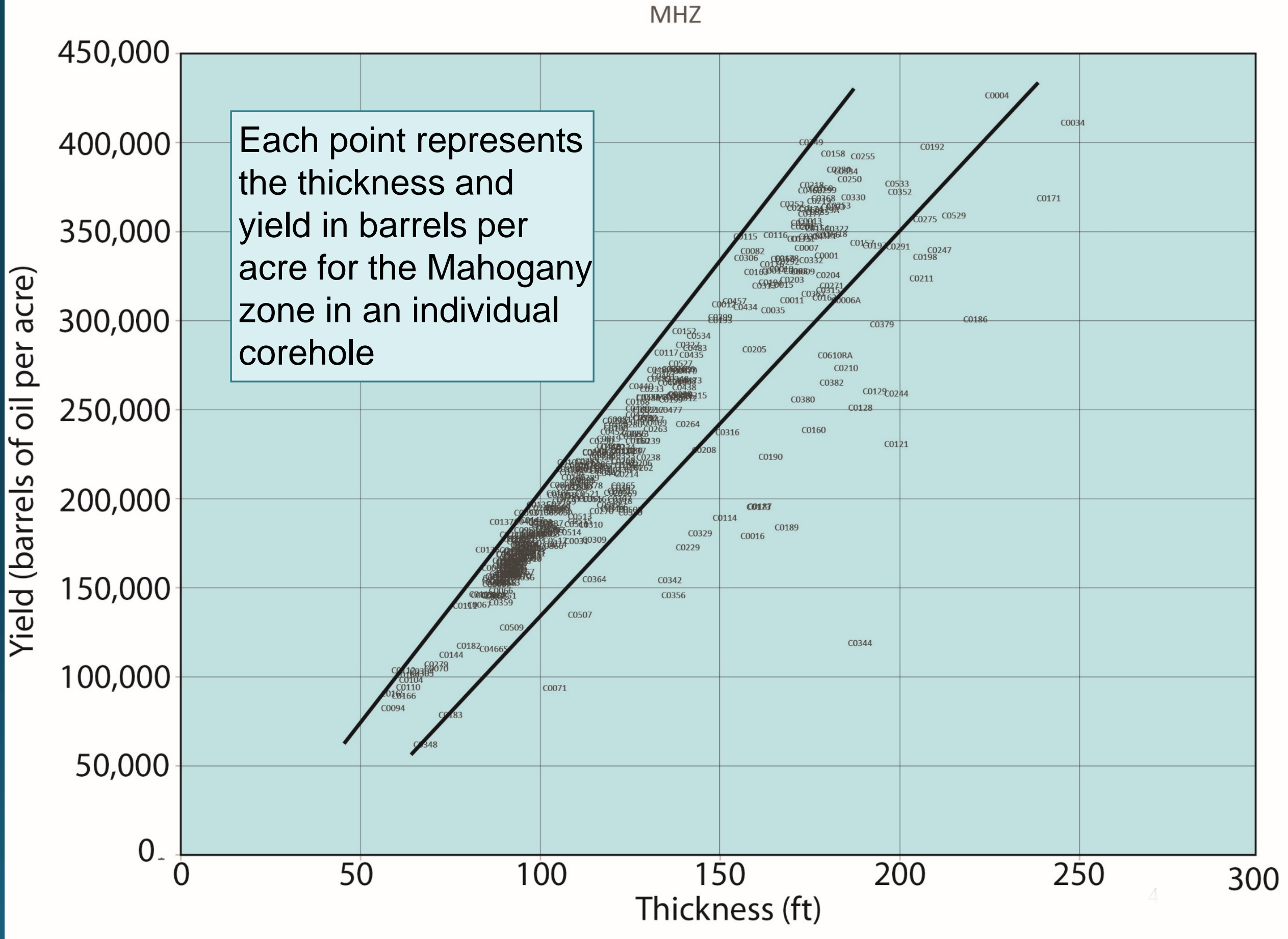




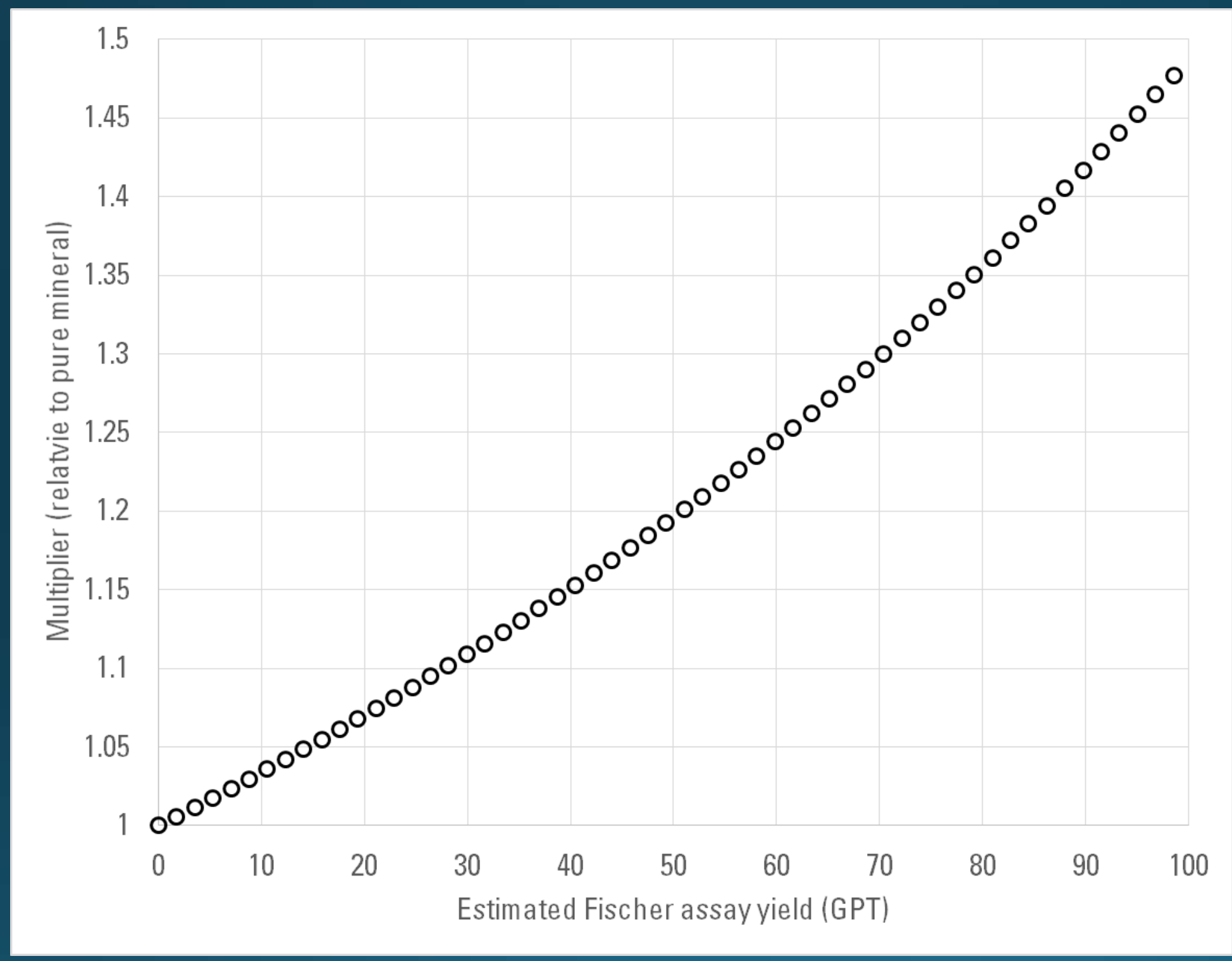

These values were calculated based on the following assumptions:

Mineral density $\left(\right.$ rho-M) $=2.6 \mathrm{~g} / \mathrm{cm}^{3}$ Kerogen density (rho-K) $=1.1 \mathrm{~g} / \mathrm{cm}^{3}$ Fischer assay yield (GPT), FA $=2 \times$ TOC Kerogen content (wt. \%), $\mathrm{K}=\mathrm{TOC} / \mathrm{o} .8$

Calculations

Oil shale density (rho-OS)

rho-OS $=\mathrm{K} \times$ rho $-\mathrm{K}+(1-\mathrm{K}) \times$ rho- $\mathrm{M}$

Thickness multiplier (relative to pure mineral) $\mathrm{TM}=1 /$ (rho-OS/rho-M)

Note

TOC = total organic carbon, wt. \%

Only a small percentage of the increases in thickness are due to increases in kerogen. The rest are due to increases in mineral matter, including clay. 
There is considerable research that shows that organic matter is attached to and protected by fine-grained mineral matter, mainly clay:

- Salmon et al. (2000, Organic Geochemistry 31, 463-474), Protection of organic matter by mineral matrix in a Cenomanian black shale.

- Kennedy et al. (2002, Science 25, 657-660), Mineral surface control of organic carbon in Black Shale.

- Hedges and Keil (1995, Marine Chemistry 49, 81-115) Sedimentary organic matter preservation: an assessment and speculative synthesis.

- Keil and Hedges (1993, Chemical Geology, 107, 385-388), Sorption of organic matter to mineral surfaces and the preservation of organic matter in coastal marine sediments. 


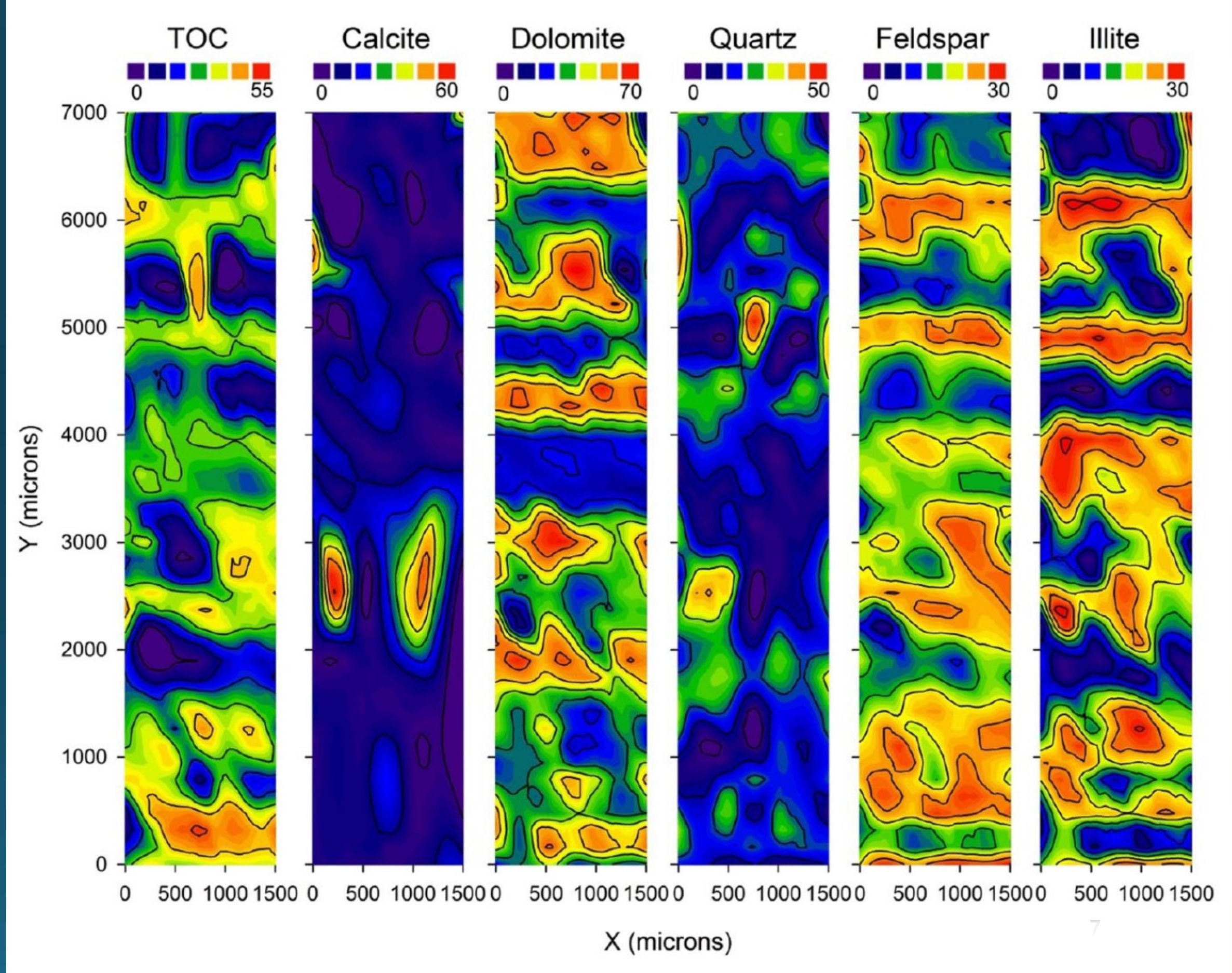


Herein we use two publically available databases: (1) Piceance Basin oil shale database (for more information, see Johnson et al., 2010) and (2) Mineral Occurrence data for the Eocene Green River Formation in the Piceance and Uinta Basins (Johnson et al., 2017; DOI: 10.5066/F7XP7334) and a soon to be released database that compiled percentages of laminated and "blebby" oil shale for coreholes in the Piceance Basin to study the relationship between mineral matter and organic matter in the Green River Formation, Piceance Basin, Colorado. 
The Laramide orogeny in the Rocky Mountain region (Late Cretaceous through Eocene) created a number of basins that were occupied by large permanent lakes. Lake Uinta occupied the Uinta and Piceance Basins.

Lake Uinta had two deep depocenters with shallower water over the Douglas Creek arch. The lake was permanently stratified with a highly alkaline and saline lower layer and a fresher upper layer (Bradley, 1963; Bradley and Eugster, 1969).

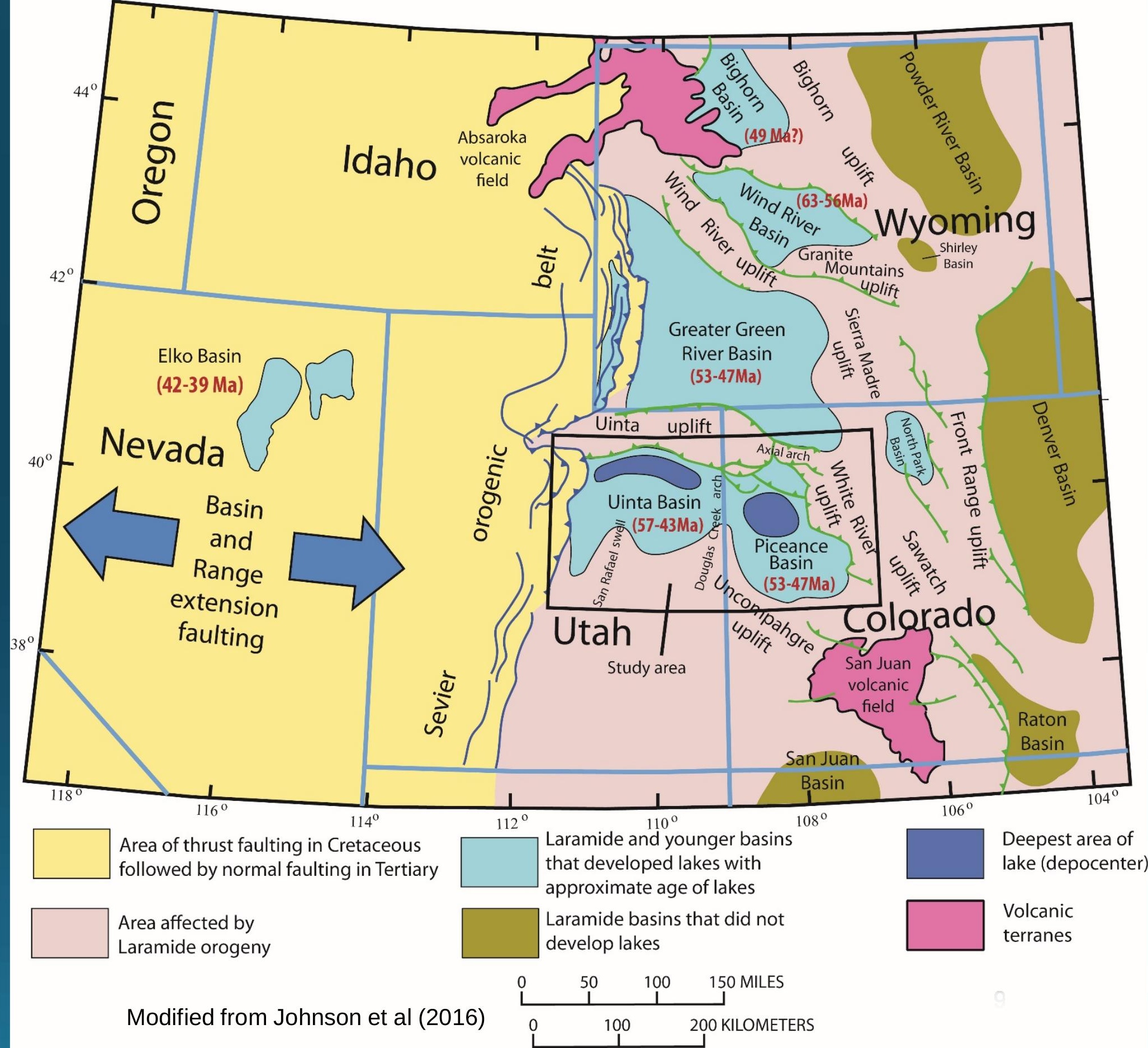


The two deep depocenters can be seen on this west to east cross section across the Uinta and Piceance Basins and the Douglas Creek arch that separates them. The Douglas Creek arch subdivided the lake into two during much of the early freshwater period, but a single lake extended across the arch during the saline period.

In the heart of the Uinta Basin depocenter there is more than 9,500 ft of continuous, mostly fine-grained offshore lacustrine rock (yellow line). Maximum thickness of offshore lacustrine rock in the Piceance depocenter is about 4, $000 \mathrm{ft}$ (red line).

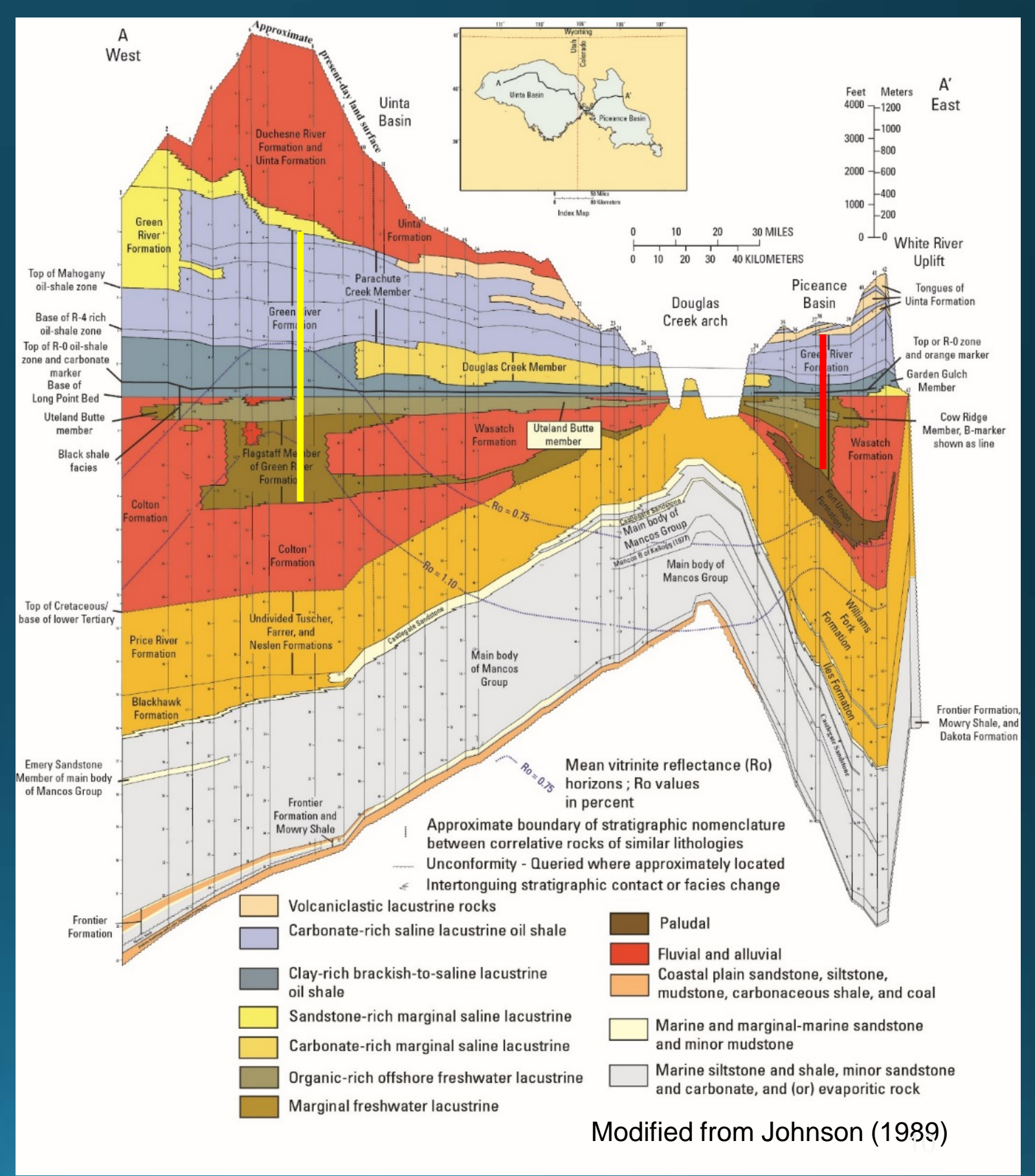


The oil shale interval in the Uinta and Piceance Basin has been traditionally subdivided into the lower, clay-rich Garden Gulch Member and upper carbonate-rich (mainly dolomite) Parachute Creek Member. Cashion and Donnell (1972) subsequently subdivided the two members into 18 laterally persistent, time stratigraphic rich and lean zones that can be found in both basins.
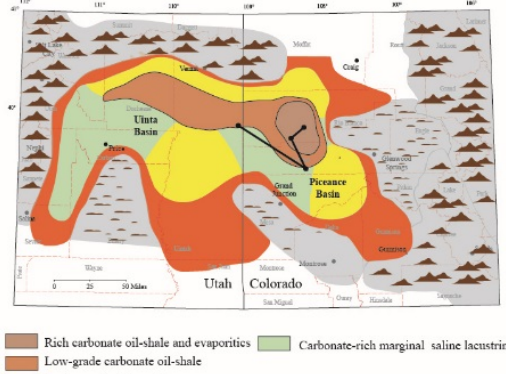

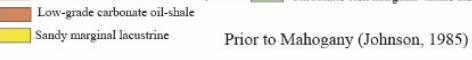
\#USGS
A

East
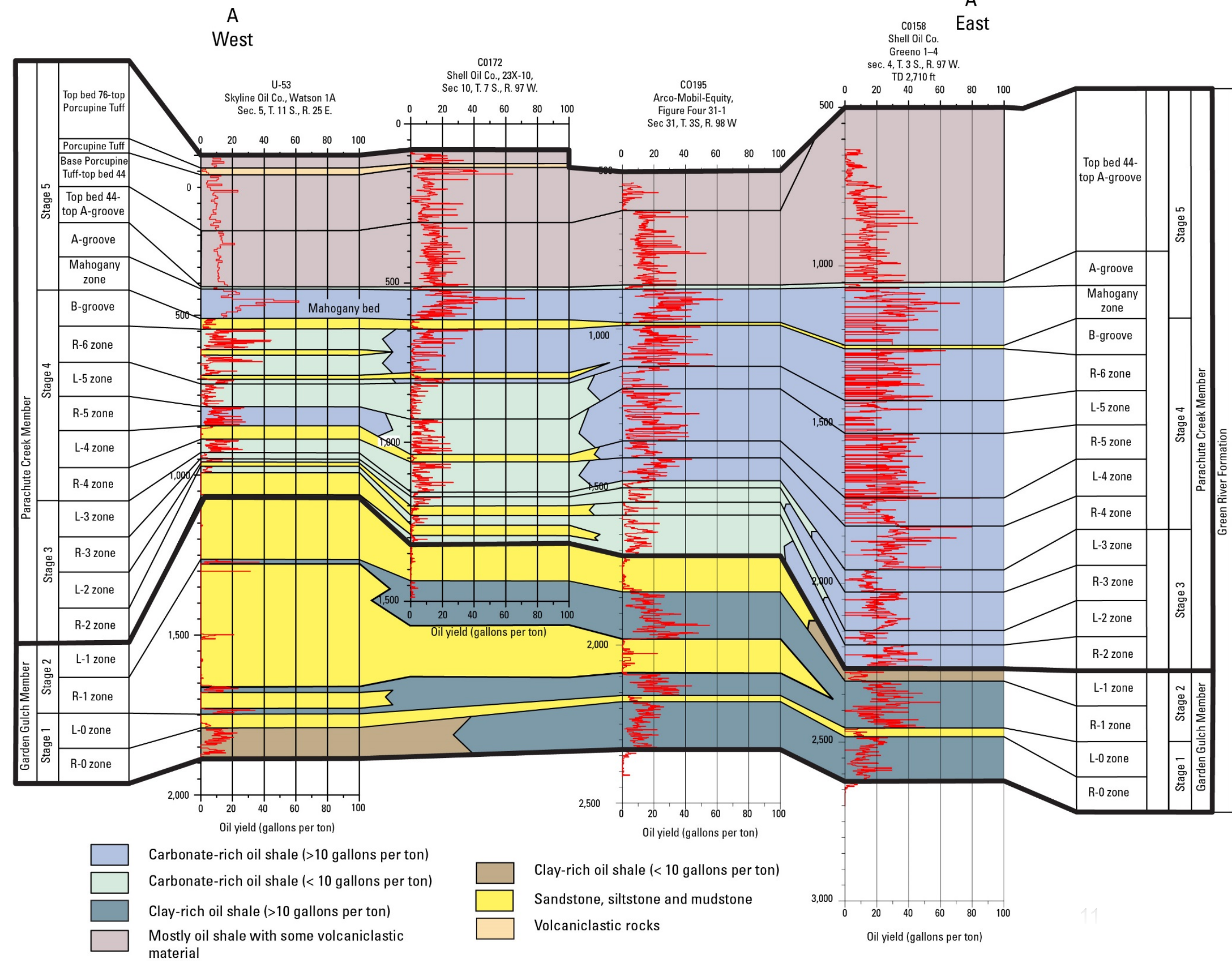
The Garden Gulch has been traditionally referred to as the illitic member as it contains about $20-40 \%$ illite. The Parachute Creek has been referred to as the dolomitic member, but both units have about the same amount of dolomite.

Note the increase in dawsonite $\left[\mathrm{NaAl}\left(\mathrm{CO}_{3}\right)(\mathrm{OH})_{2}\right]$, nahcolite $\left[\mathrm{NaHCO}_{3}\right]$, and feldspar where illite disappears.

口Quartz $\quad \square$ Kspar $\quad \square$ Albite $\quad$ Buddingtonite

$\square$ Analcime $\square$ Calcite $\quad$ Dolomite Nahcolite

口Dawsonite allite $\quad$ Pyrite $\quad$ Halite

$\begin{array}{lllllllllll}0 \% & 10 \% & 20 \% & 30 \% & 40 \% & 50 \% & 60 \% & 70 \% & 90 \% & 90 \% & 100 \%\end{array}$

Mahogany Zone

R-6

$L-5$

R-5

$\mathrm{L}-4$

R-4

L-3

R-3

L-2

R-2

L-1

R-1

L-0

R-0

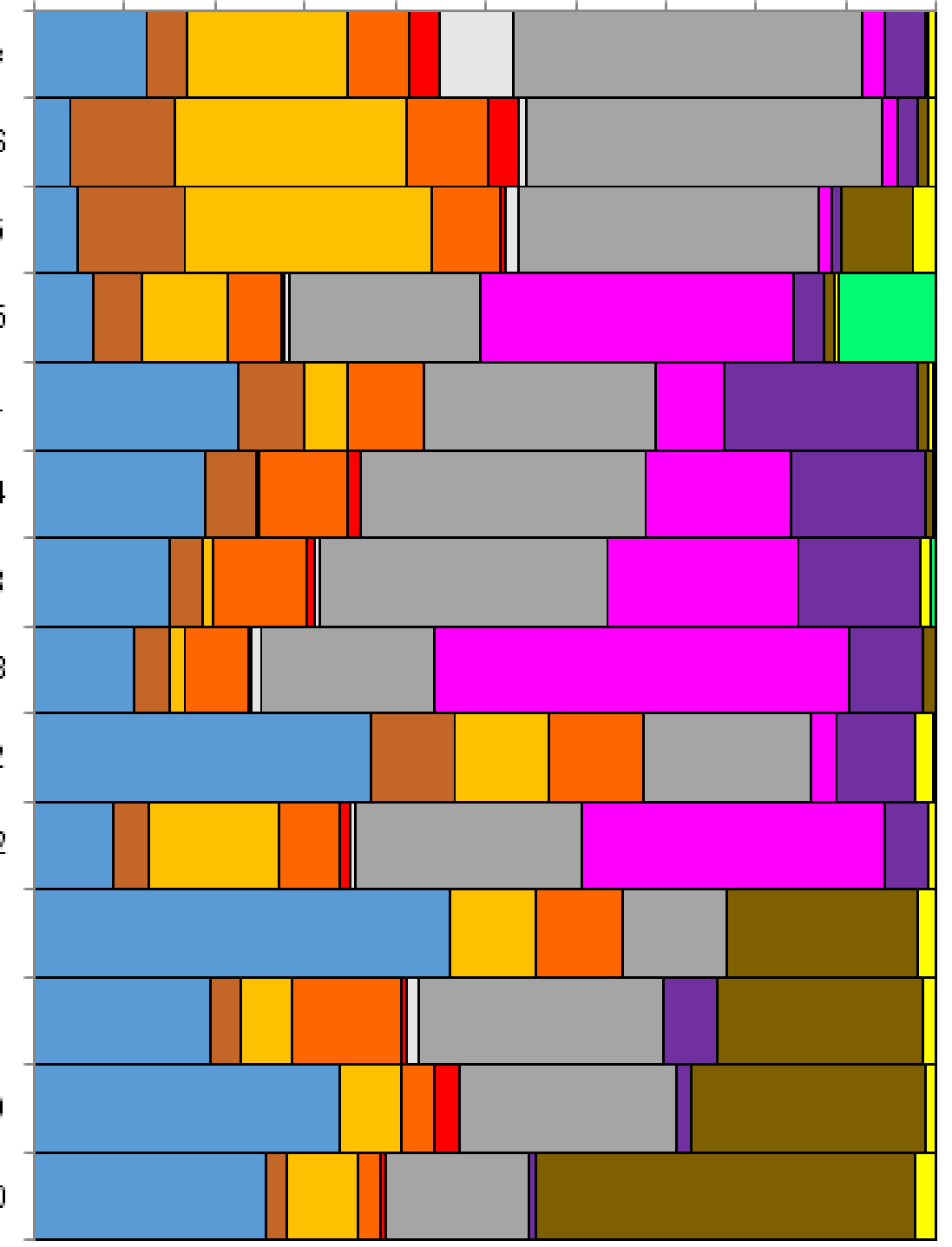


Based on recent work, the contact between the Garden Gulch and Parachute Creek Members appears to be largely if not totally diagenetic.

"The disappearance of clay minerals does not reflect a change in the sedimentary mixture, but rather the diagenetic alteration of the clay mineral component into authigenic feldspar (including a significant buddingtonite $\left[\mathrm{NH}_{4} \mathrm{AlSi}_{3} \mathrm{O}_{8}\right]$ component in the $\mathrm{K}$-feldspar) and dawsonite $\left[\mathrm{NaAl}\left(\mathrm{CO}_{3}\right)(\mathrm{OH})_{2}\right]$." (Boak et al., 2016)

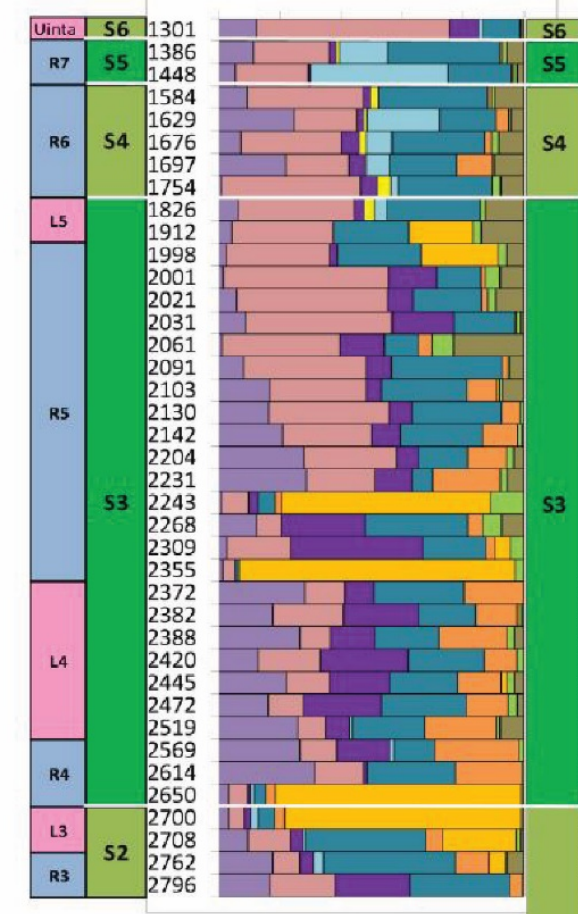

$\square$ Quartz

$\square$ Feldspars

Buddingtonite

$\square$ Analcime

$\square$ Calcite/Aragonite

Ferrodolomite

$\square$ Dawsonite

$\square$ Nahcolite

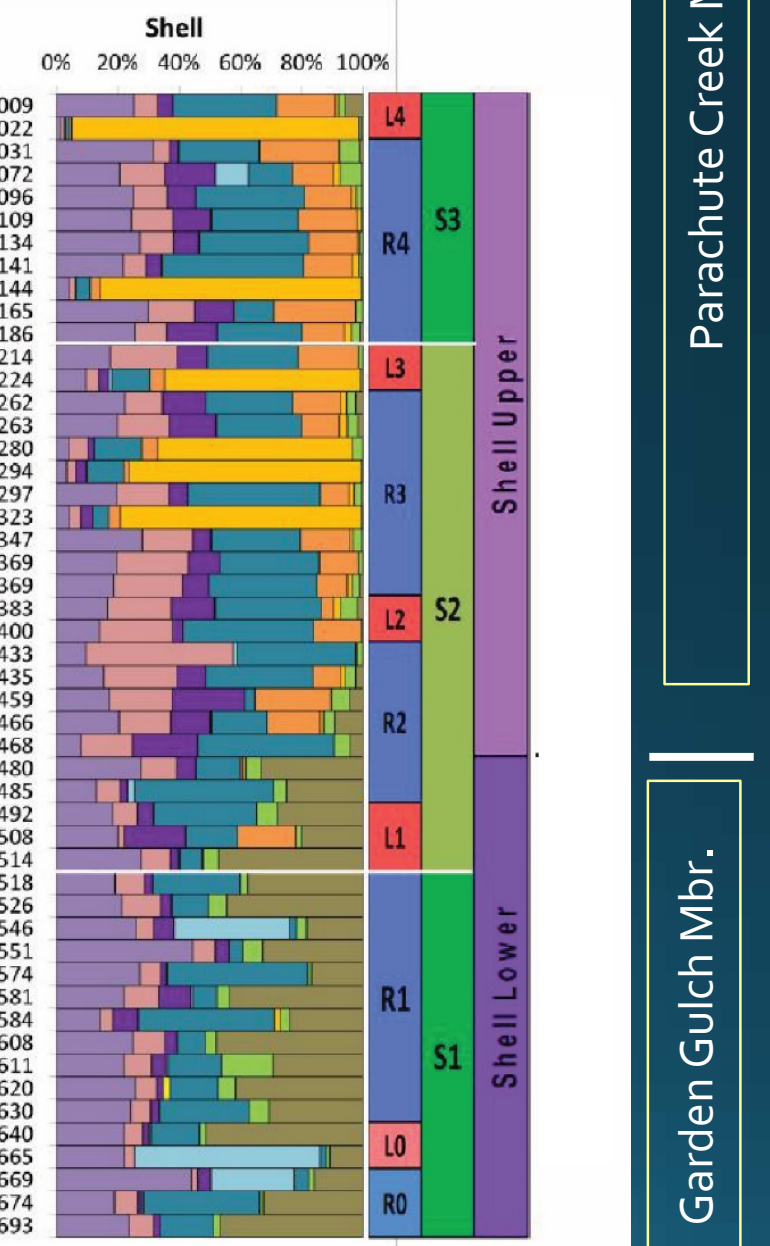


Quantitative X-ray mineralogy for the Green River Formation in a lake margin setting near Douglas Pass along the western margin of the Piceance Basin. (from Poole, 2014). Rich and lean zone picks are new to this report. Illite is present throughout the Green River Formation at this locality.

घuartz $\square$ K-feldspar $\square$ Albite $\quad$ Calcite $\square$ Dolomite $\square$ Pyrite

口Illite

$\square$ Kaolinite $\square$ Chlorite $\square$ Analcime $\square$ Anhydrite $\square$ TOC

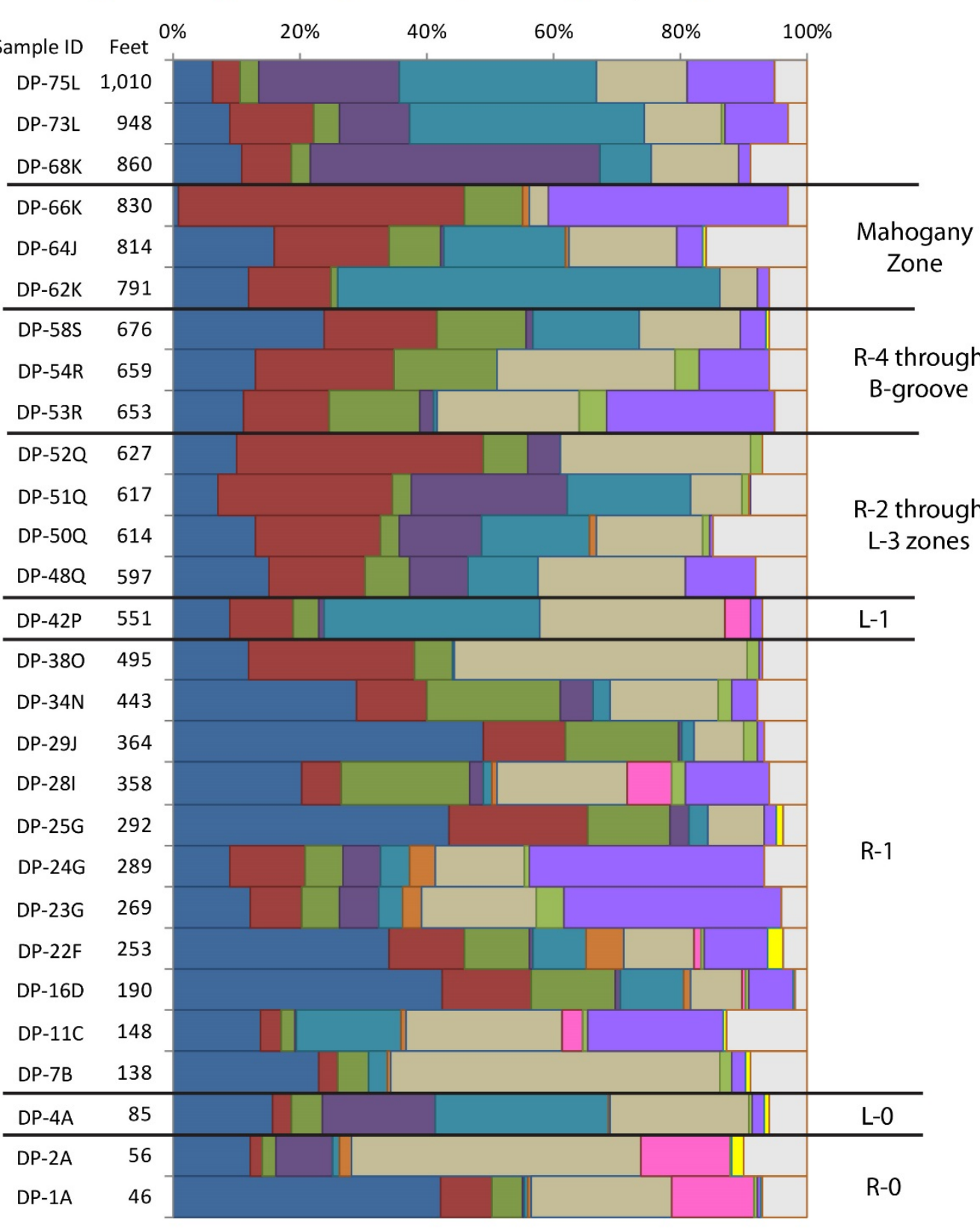


In the R-3 zone (lower part of Parachute Creek Member) illite is missing in the depocenter of the lake where it has broken down to form dawsonite $\left[\mathrm{NaAl}\left(\mathrm{CO}_{3}\right)\right.$ $\left.(\mathrm{OH})_{2}\right]$ and authigenic feldspars. Analcime $\left[\mathrm{NaAlSi}_{2} \mathrm{O}_{6} \cdot \mathrm{H}_{2} \mathrm{O}\right]$ also disappears in the depocenter.

Illite and analcime persisted in marginal areas where the lake was less saline.

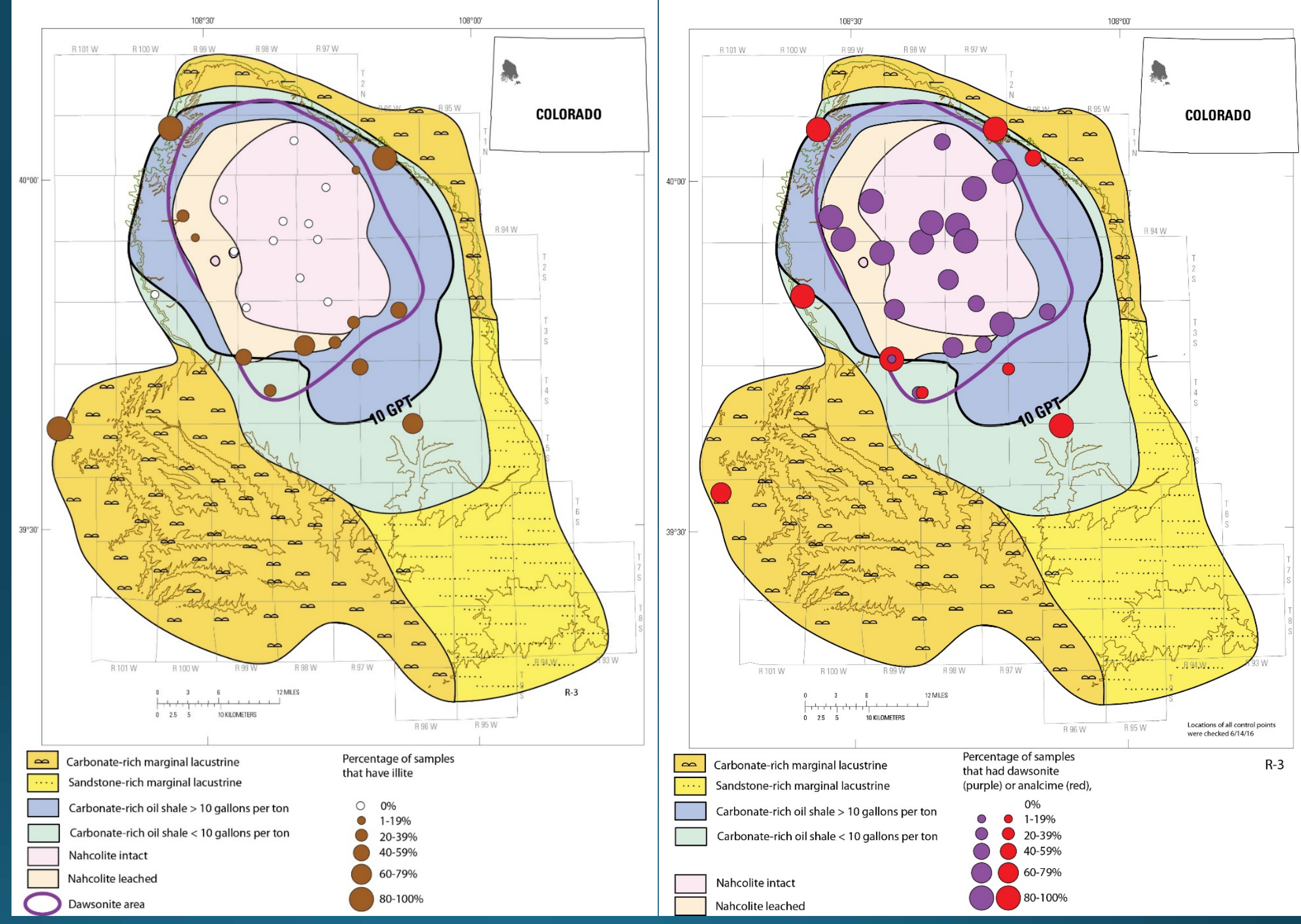

Maps generated using "Mineral Occurrence data for the Eocene Green River Formation in the Piceance and Uinta Basins" https://doi.org/10.5066/F7XP7334 
There are two types of oil shale: (1) "varved" as Bradley (1929) described, and (2) laterally transported oil shale.

Here, we will focus on just the varved oil shale but give an example of a zone that consists mainly of transported oil shale for comparison.
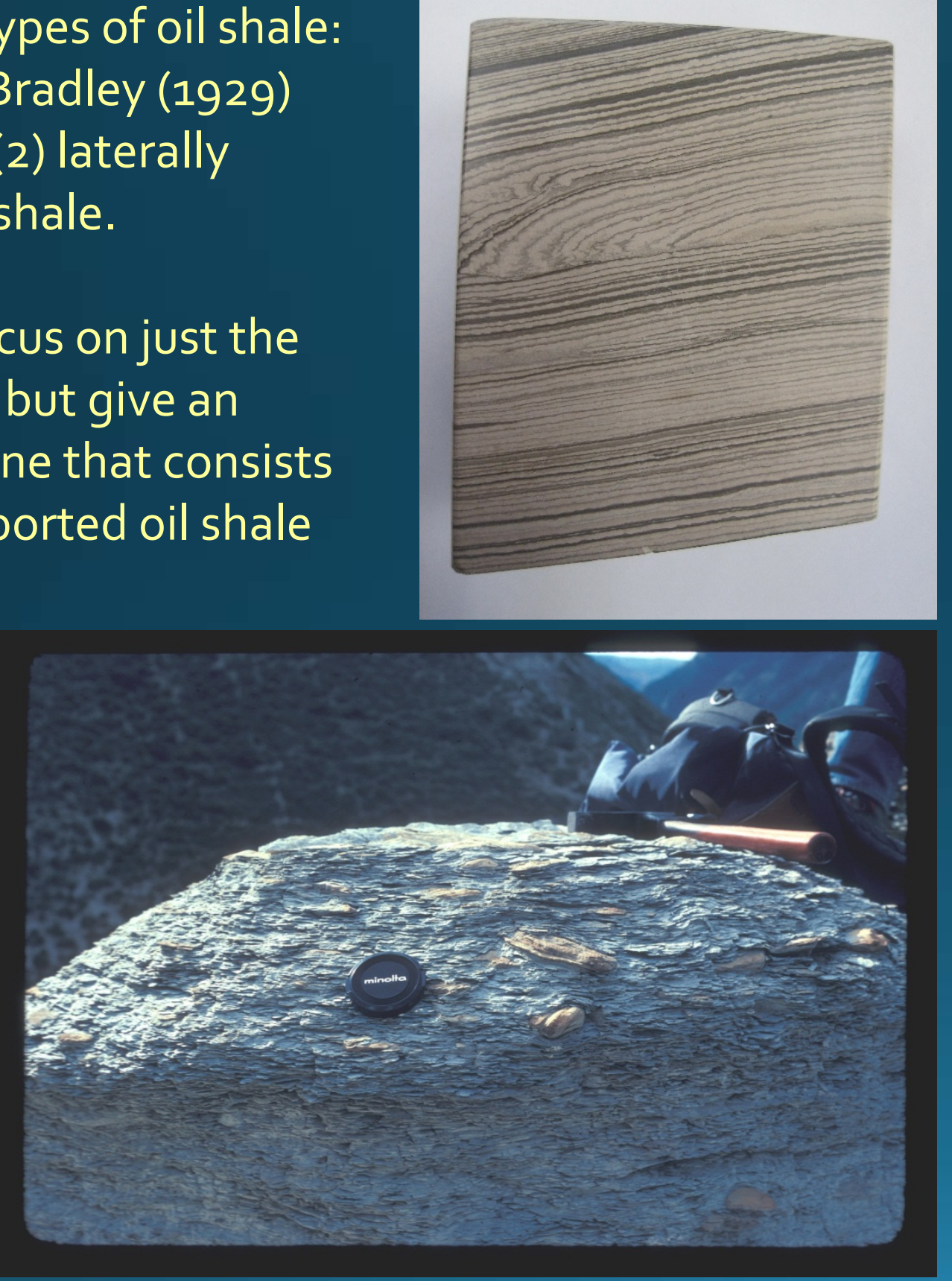

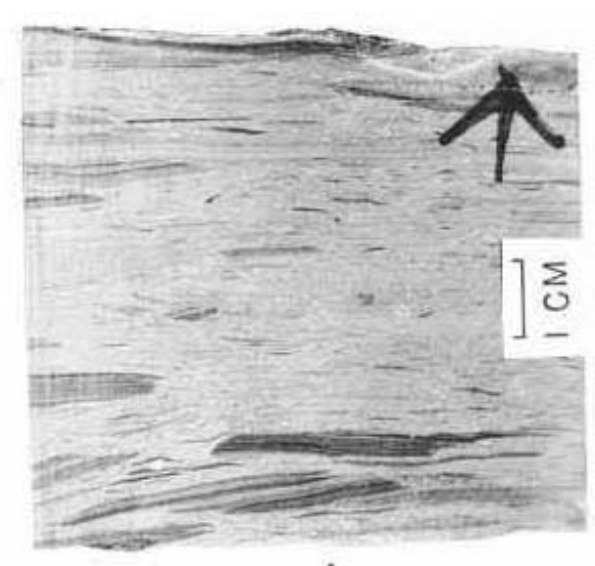

A
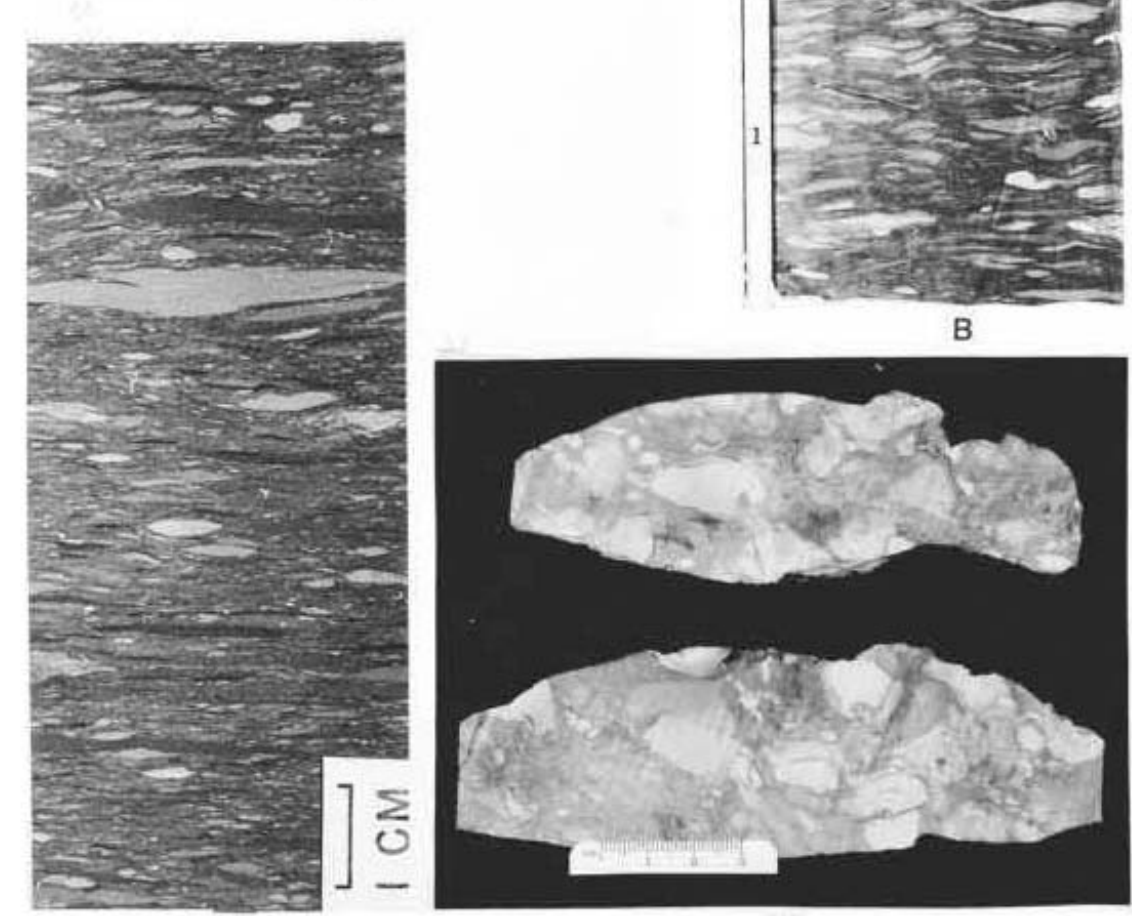

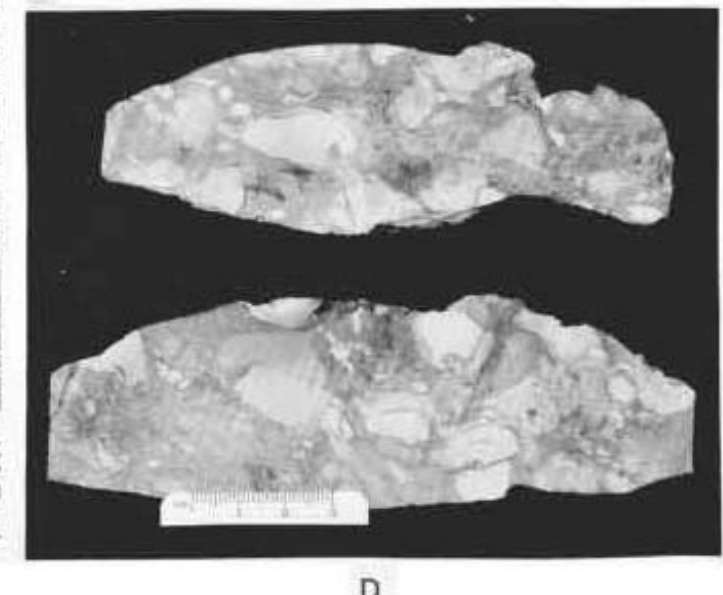

Examples of "blebby oil shale" from the central part of Lake Uinta Piceance Basin (from Dyni and Hawkins (1981) 
A. End of early saline mineral phase

Oil shale and saline mineral depocenter begins to

fill in. Offshore lacustrine conditions expand across

marginal flats.

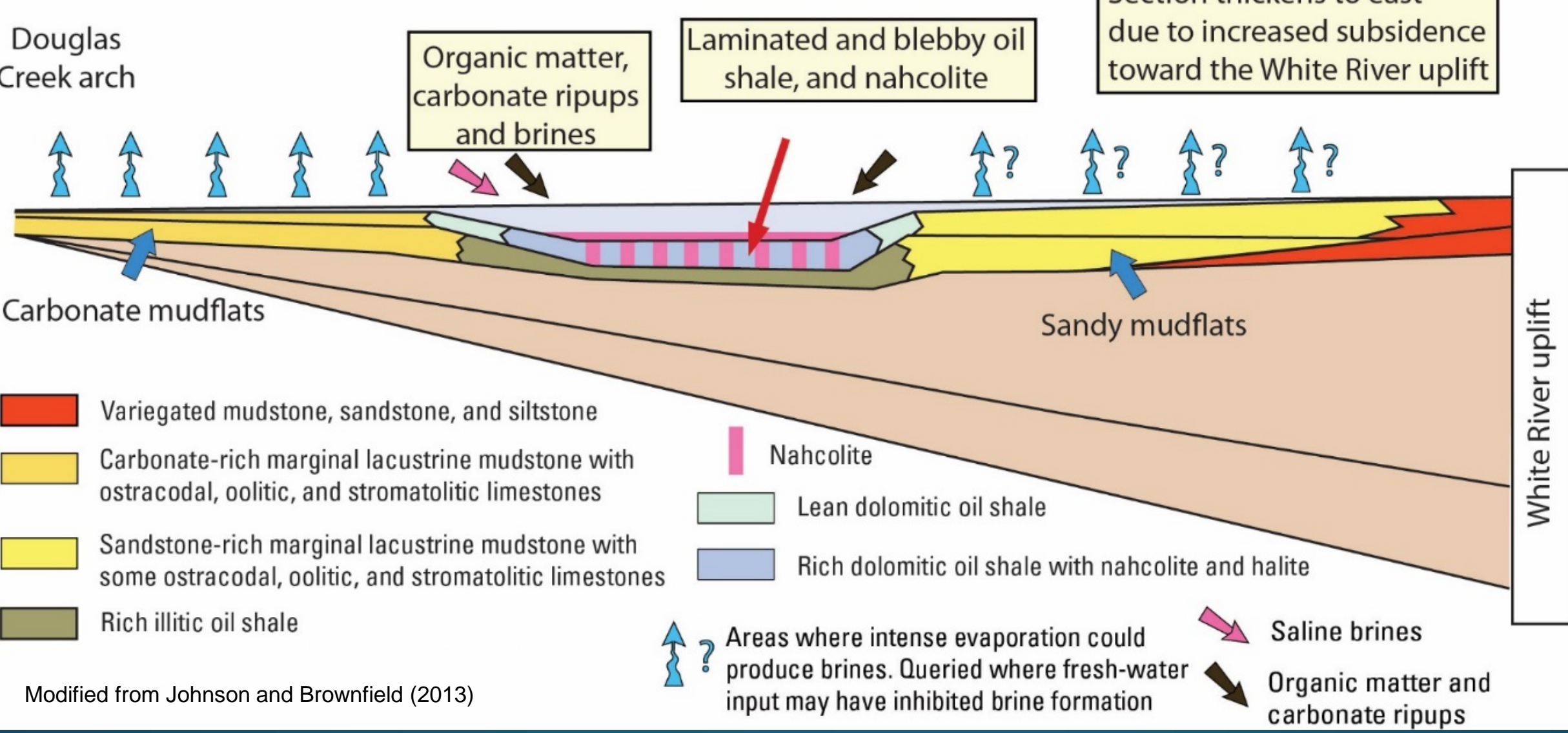

Laterally transported oil shale is most abundant in the oil shale depocenter during the early period of saline Lake Uinta when the lake was surrounded by broad marginal shelves that produced highly saline brines. When the brines washed into the depocenter they appear to have brought abundant ripped up organic-rich material with them. 

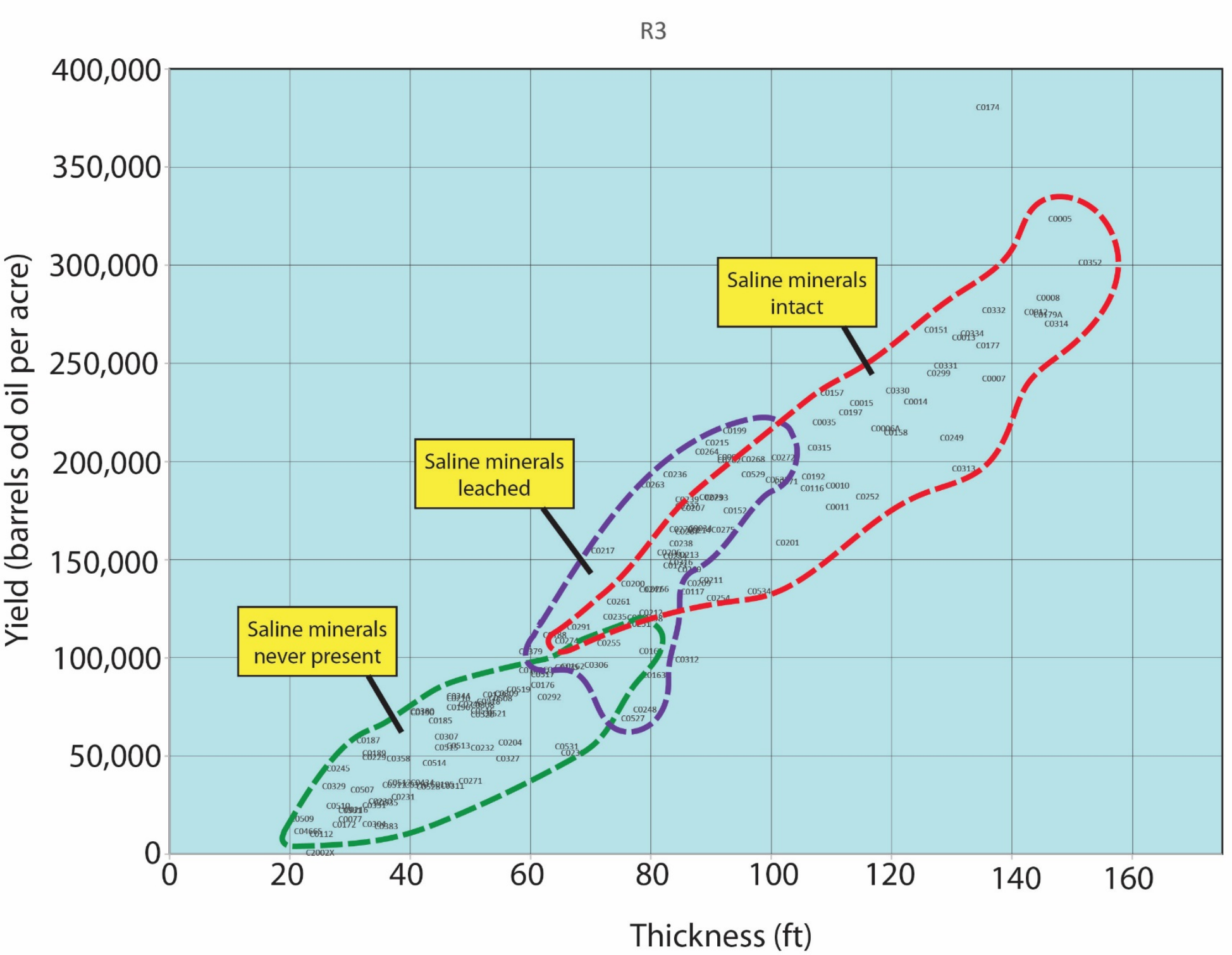

The R-3 zone can be subdivided into three areas: (1) where saline minerals are intact, (2) where saline minerals have been leached, and (3) where saline minerals were never deposited. Saline minerals can increase the thickness of the section where present and can thin the section where leached out due to collapse.

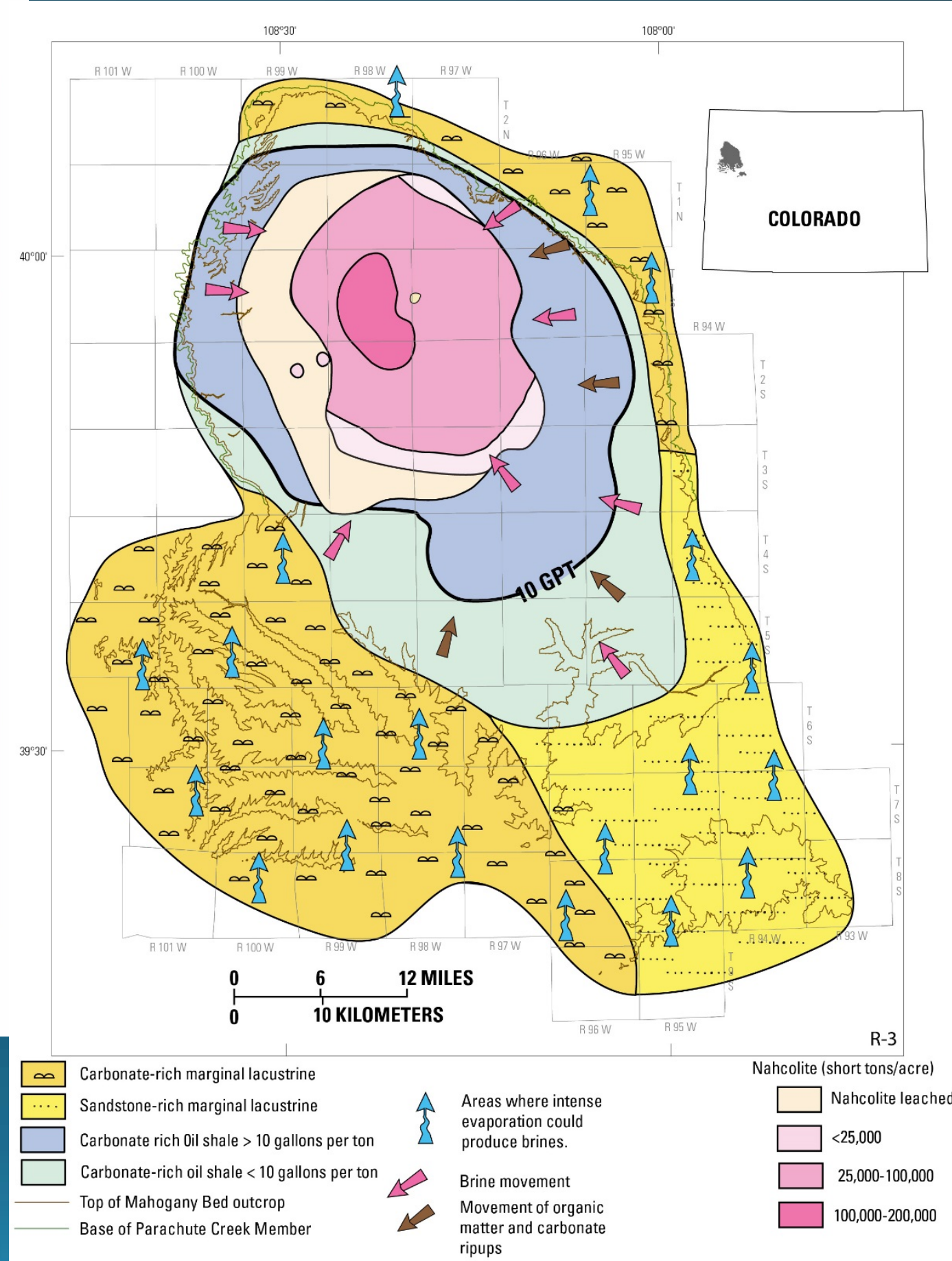




\section{B. Just prior to Mahogany}

Deepwater oil shale deposition expands across former marginal shelf areas. The deep brine layer expands to nearshelf edge at end of the illitic phase. Marginal shelves, where brines could evolve, have been greatly reduced. Mainly laminated oil shale is deposted on former shelf areas.

Douglas

Creek arch

Carbonate

mudflats

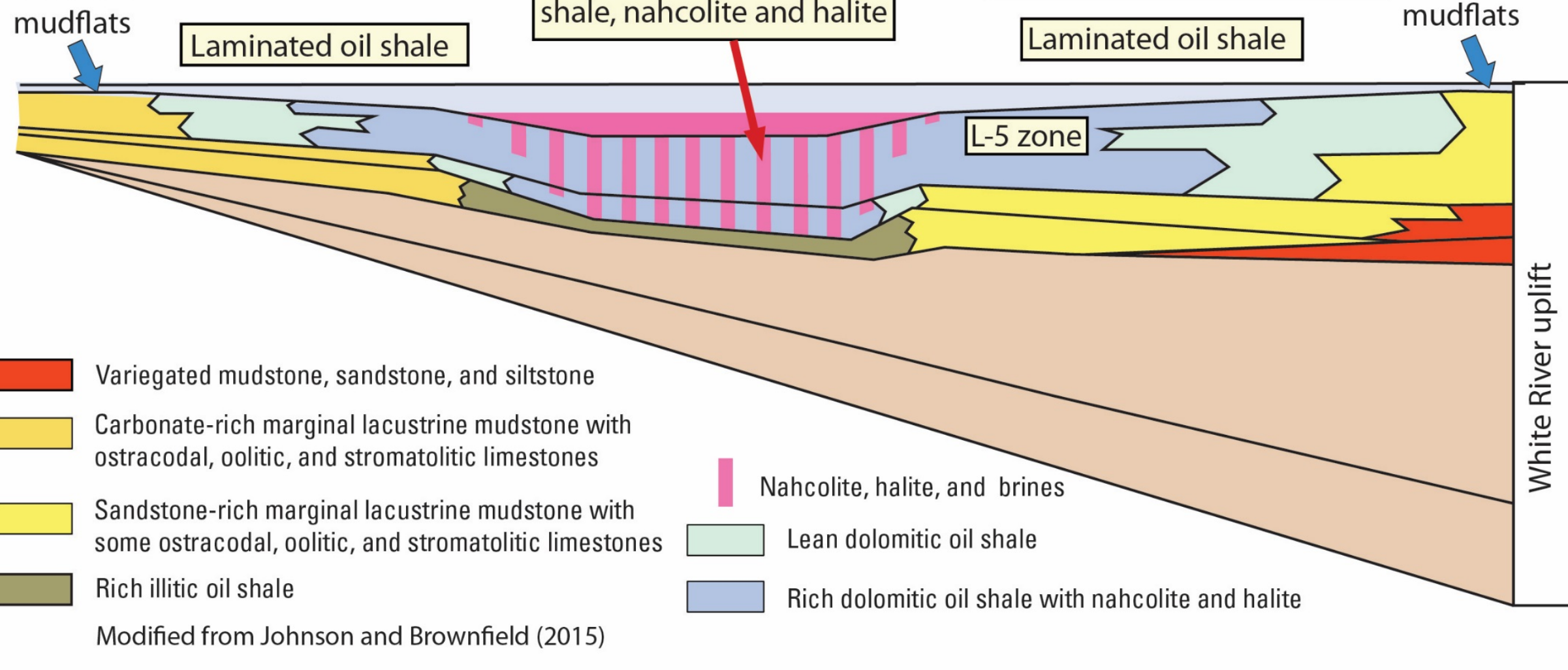

Laminated and blebby oil

Section thickens to east

due to increased subsidence

toward the White River uplift

Lake Uinta gradually expanded across the marginal shelves, and by the beginning of Mahogany zone deposition, deep water conditions existed across much of the shelves. The Mahogany is largely laminated and contains little transported oil shale. 
Herein we focus on two largely laminated intervals deposited late in the history of Lake Uinta:

(1) Mahogany zone, and

(2) bed 44 interval
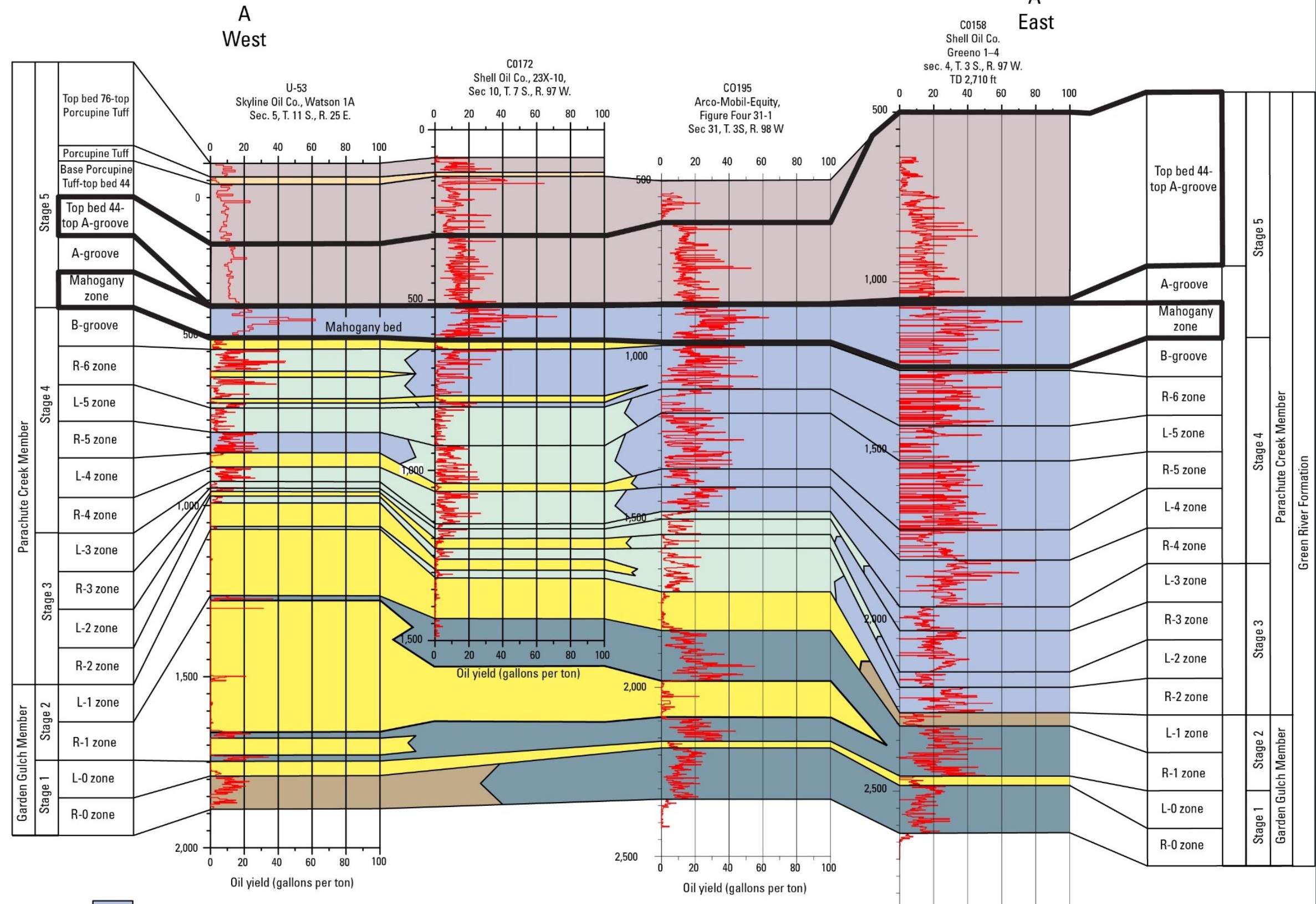

¿USES
Carbonate-rich oil shale ( $>10$ gallons per ton) Carbonate-rich oil shale $(<10$ gallons per ton) Clay-rich oil shale (>10 gallons per ton) Mostly oil shale with some volcaniclastic materia
Clay-rich oil shale $(<10$ gallons per ton

Sandstone, siltstone and mudstone Volcaniclastic rocks

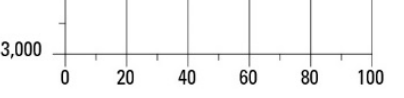

Oil yield (gallons per ton) 


\section{₹USGS}
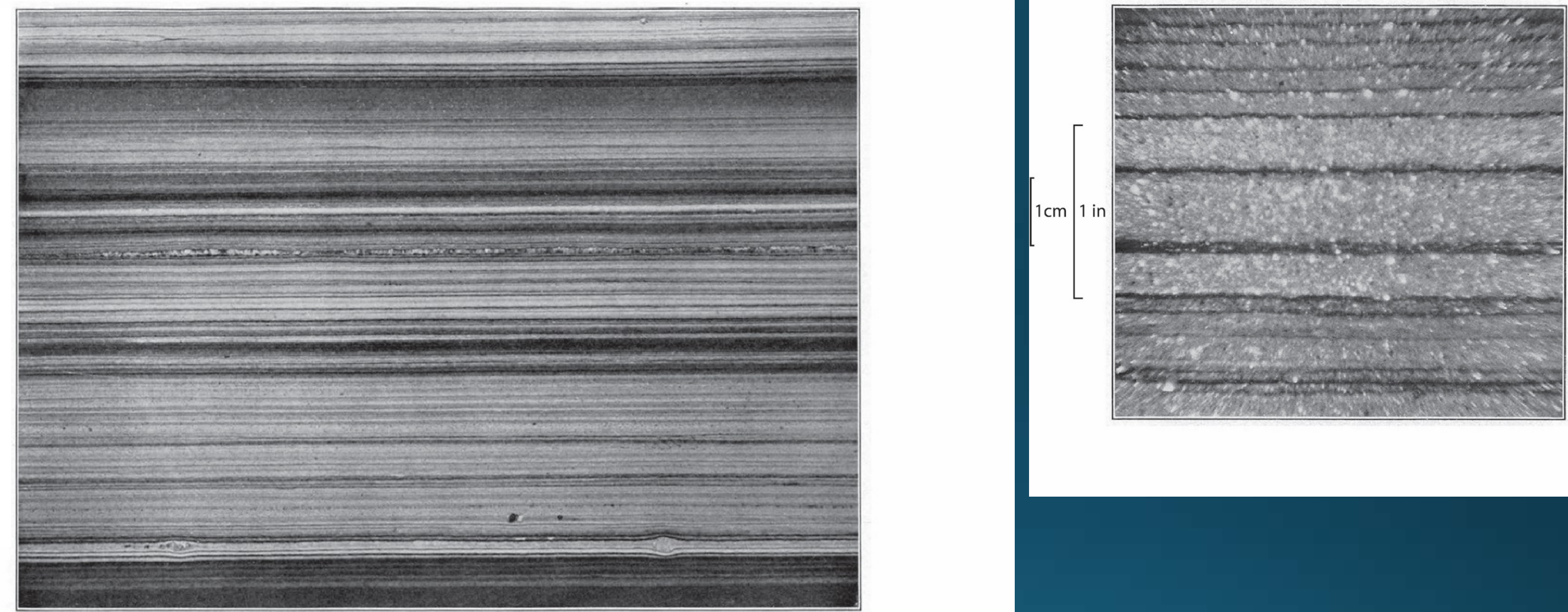

Photomicrographs of varves from Bradley (1929) Varves on the left average $1.16 \mathrm{~mm}$. The thickest varve on the right is about a $\mathrm{cm}$. The mineral-rich layers on the right were described by Bradley (1929) as "finegrained limey sandstone." These layers resemble the distal portions of turbidites in modern lakes (Ludlam, 1969; 1974) and thus would not be annual varves. 
During deposition of the Mahogany zone, Lake Uinta expanded to cover most of the former marginal shelves in the Uinta and Piceance Basins. It was recently proposed by Johnson et al. (2016) that the Mahogany has been depleted of some of its original kerogen by hydrocarbon generation and migration in the structurally deepest part of the Uinta Basin (outlined in red, black arrow). Note the decrease in gallons per ton values in that area.

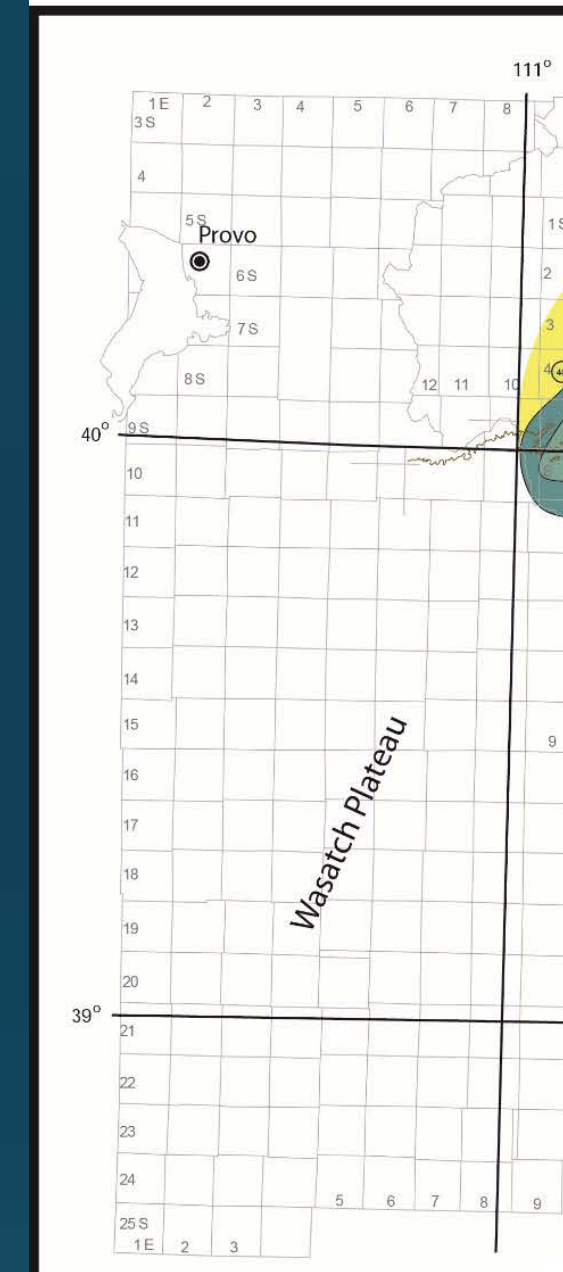

Gallons per ton with \begin{tabular}{c} 
Fischer assay \\
\hline$>3 \quad \square \quad 18-21$
\end{tabular}

$\begin{array}{ll}3-6 \quad \square \quad \\ \square-9 & \square-24\end{array}$

\begin{tabular}{l}
$6-9 \square 24-27$ \\
\hline-12
\end{tabular} $12-15 \square-30-33$ 15-18

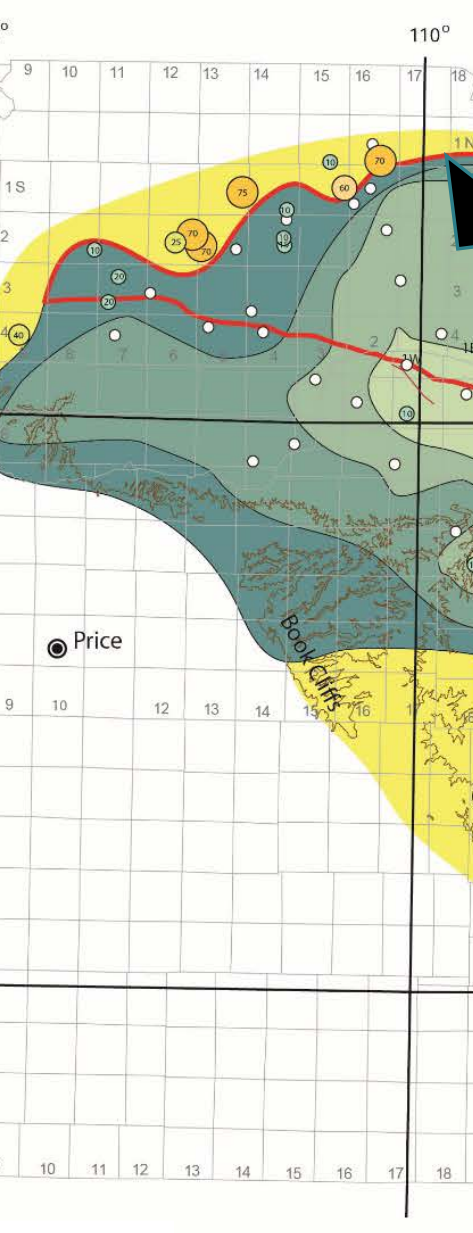

Depositional settings

Marginal lacustrin Fluvial and alluvial 
Note that isopach lines for the Mahogany zone (red) and in-place kerogen measured as barrels of oil per acre (blue) parallel each other except in marginal areas, defined by yellow line, where there was abundant clastic input from rivers.

The Mahogany zone is mainly laminated, the percent of transported oil shale (circles) is very low.

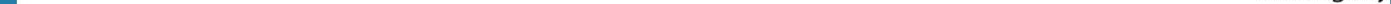


All of those points fall near the margins of the basin where major rivers entered the lake. We suggest that the Mahogany zone contains large amounts of coarser detrital debris in these areas.

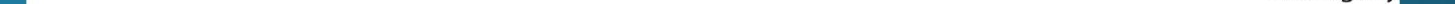


The map of the Mahogany zone on the right shows barrels per acre per foot of section. Toward the center of the lake, total mineral matter increases and it becomes increasingly more efficient at capturing organic matter possibly because it includes a greater percentage of clay there.

\section{₹USES}
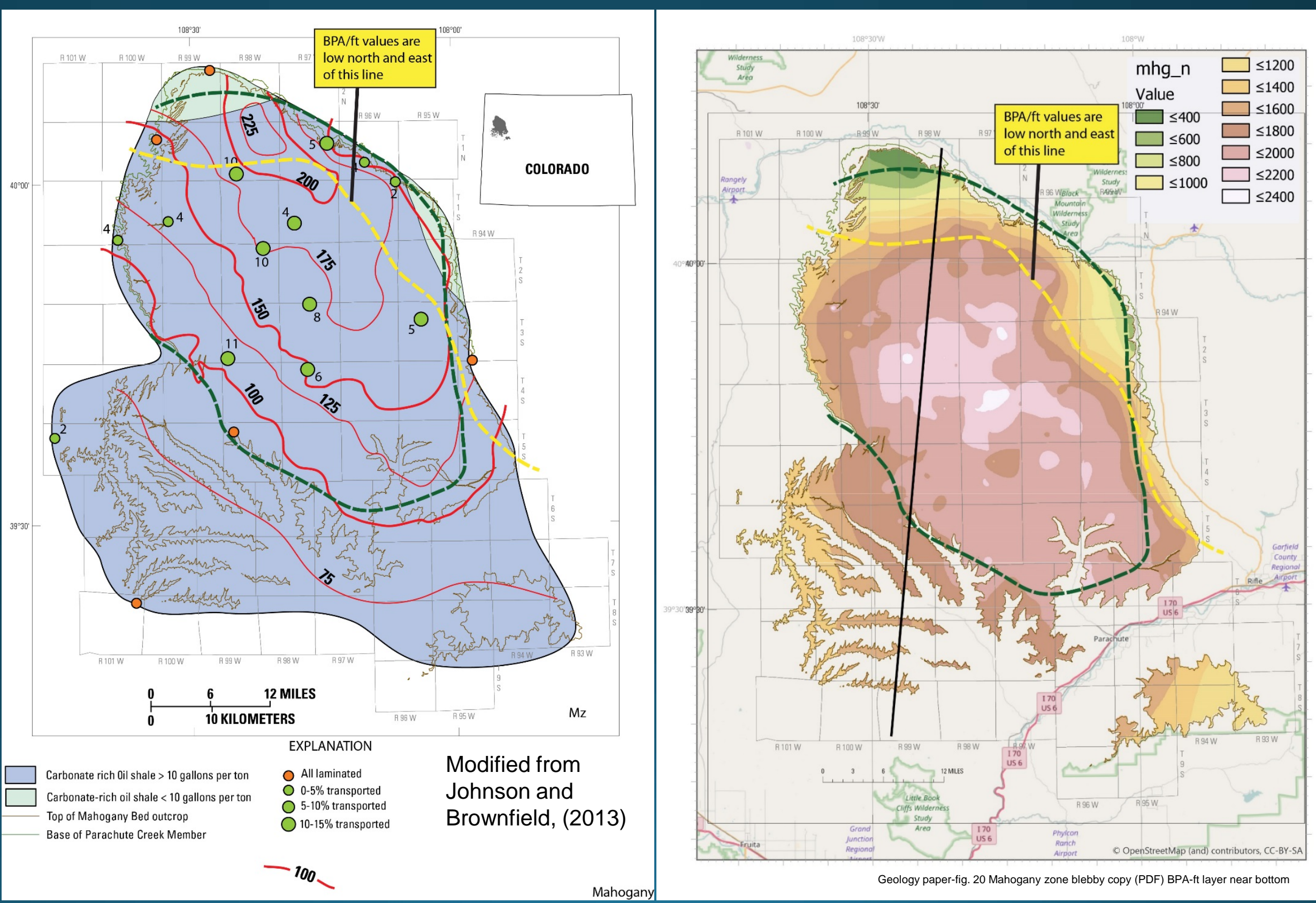
Bed 44 interval was deposited during the infilling stage of Lake Uinta when the Piceance Basin part of the lake was being filled in by volcaniclastic sediments from Wyoming. Like the Mahogany zone, the bed 44 interval is largely laminated away from sources of clastic influx.

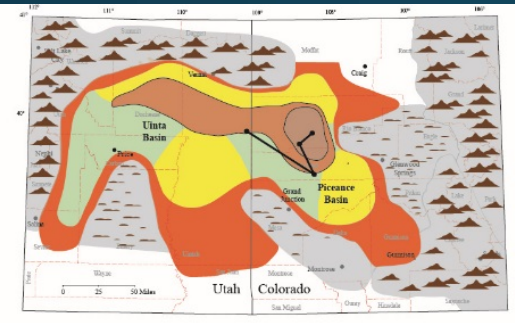

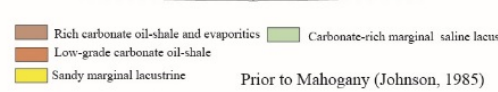

\section{ZUSGS}
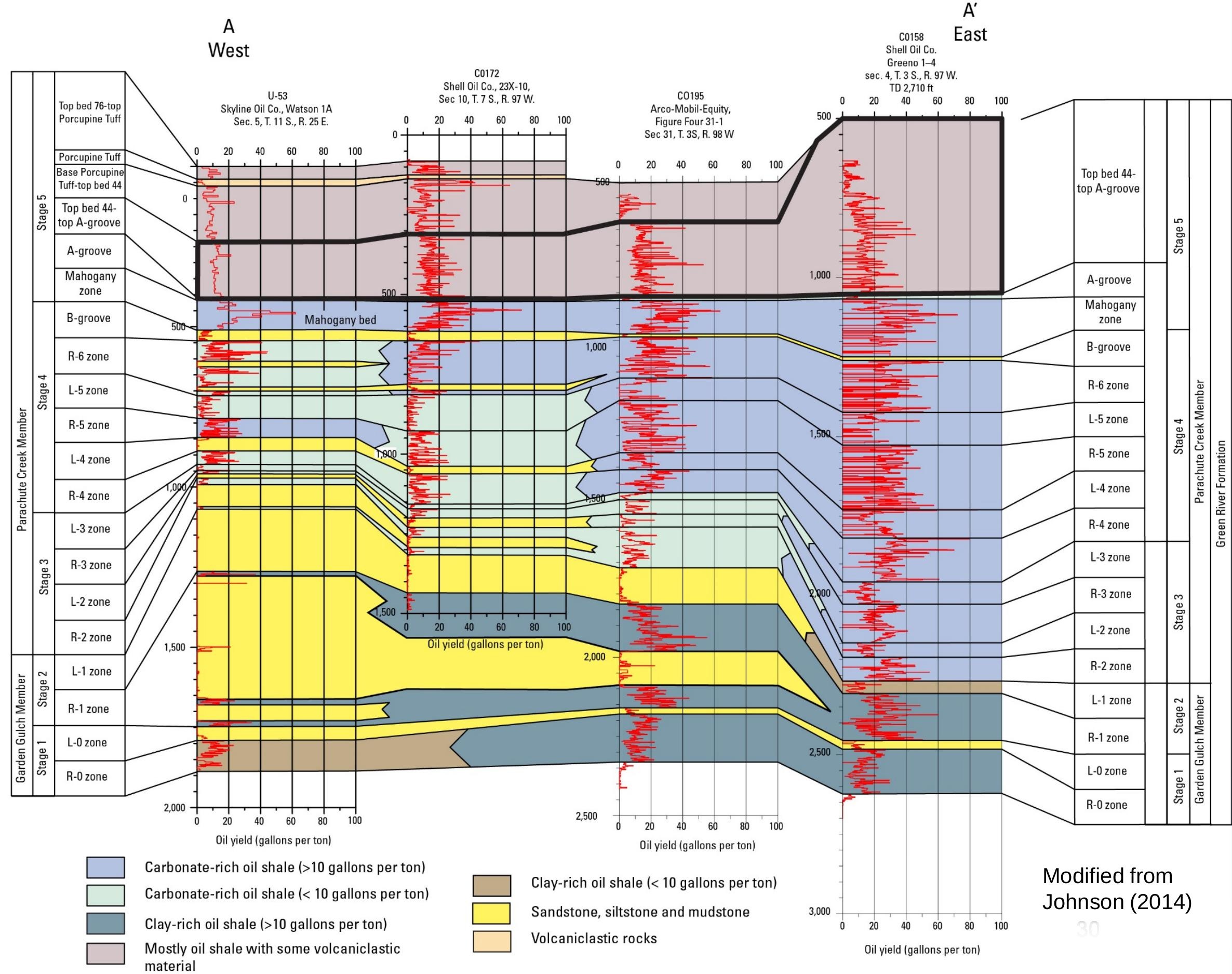
The bed 44 interval was deposited during the infilling stage of Lake Uinta when the Piceance Basin part of the lake was filled in by volcaniclastic sediments from Wyoming. Note the position of Bradley's varve study at the base of the prograding delta.

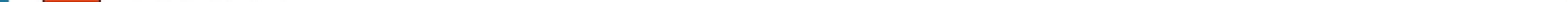


During deposition of the bed 44 interval, the Piceance part of Lake Uinta began to fill in with volcanoclastics from Wyoming.

\section{By the end of bed} 44 time, the northern part of the former depocenter had been largely filled in.

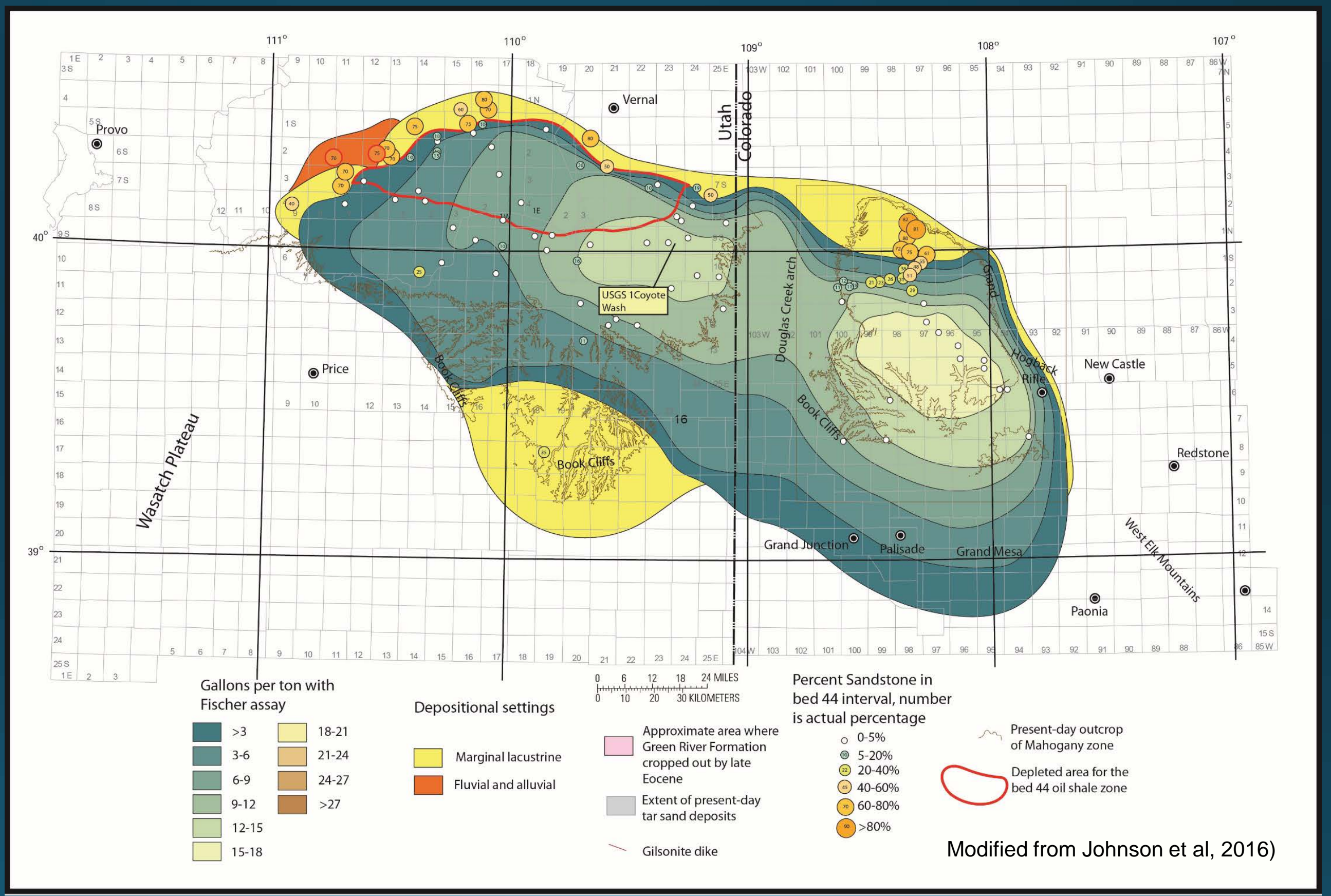


There is also a strong correlation between thickness and total kerogen (barrels per acre oil) for the bed 44 interval with most of the points falling between the two black lines.

It is also possible that the upper end curves (red dashed line)

Locations of two coreholes studied in detail fall on the trend line.

Plot generated using USGS Piceance Basin Oil Shale Database

https://pubs.usgs.gov/dds/dds-06g/ddso6g-y/

\section{ZUSGS}

Bed 44

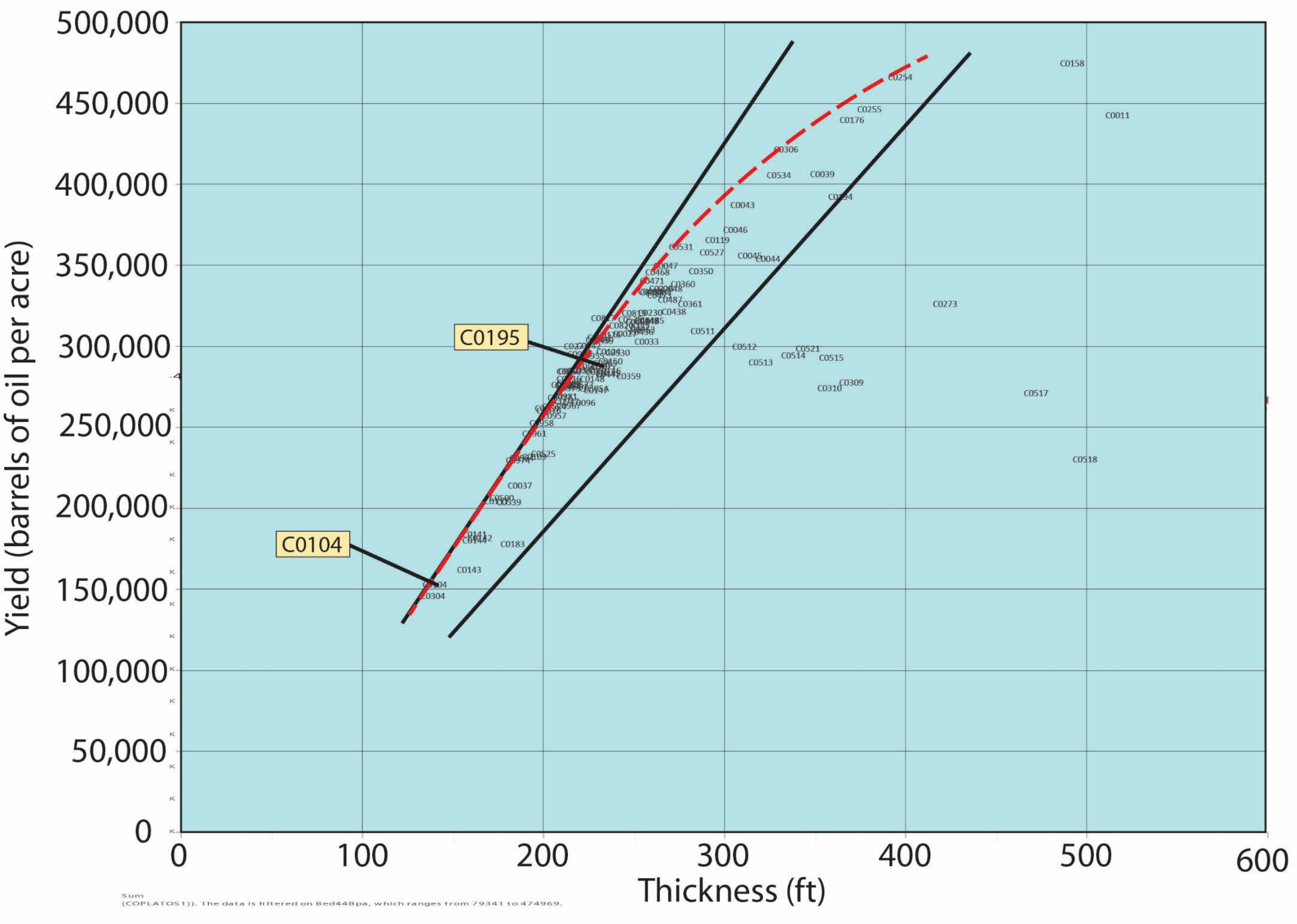


All of the points that fall off the trend include clastic tongues of the Uinta Formation.

Coreholes near Bradley's 1929 varve localities are circled.

Plot generated using USGS Piceance Basin Oil Shale Database

https://pubs.usgs.gov/dds/dds-069/ddso69-yl

\section{₹USES}

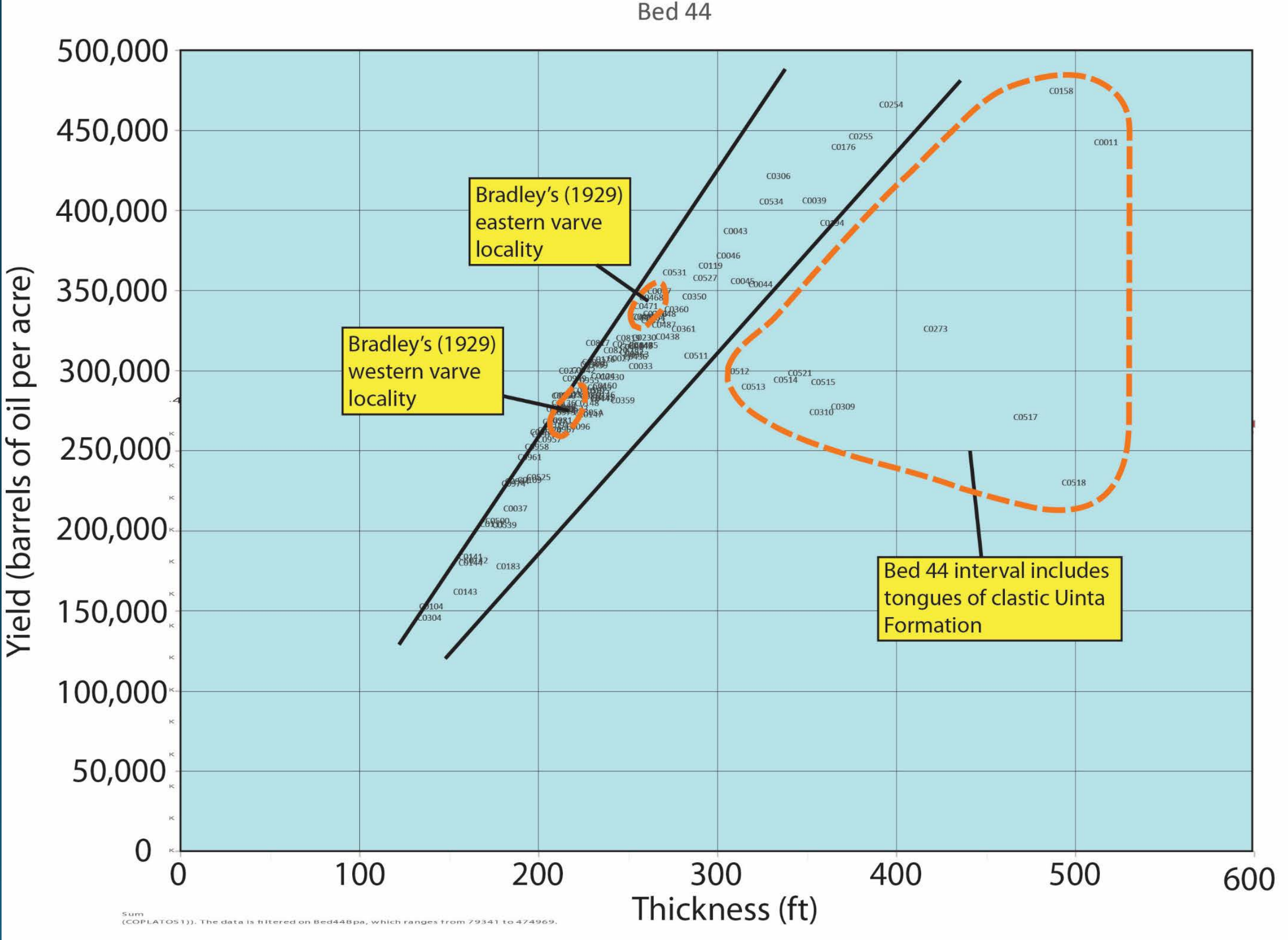




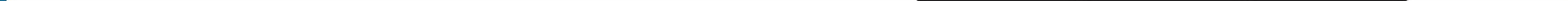




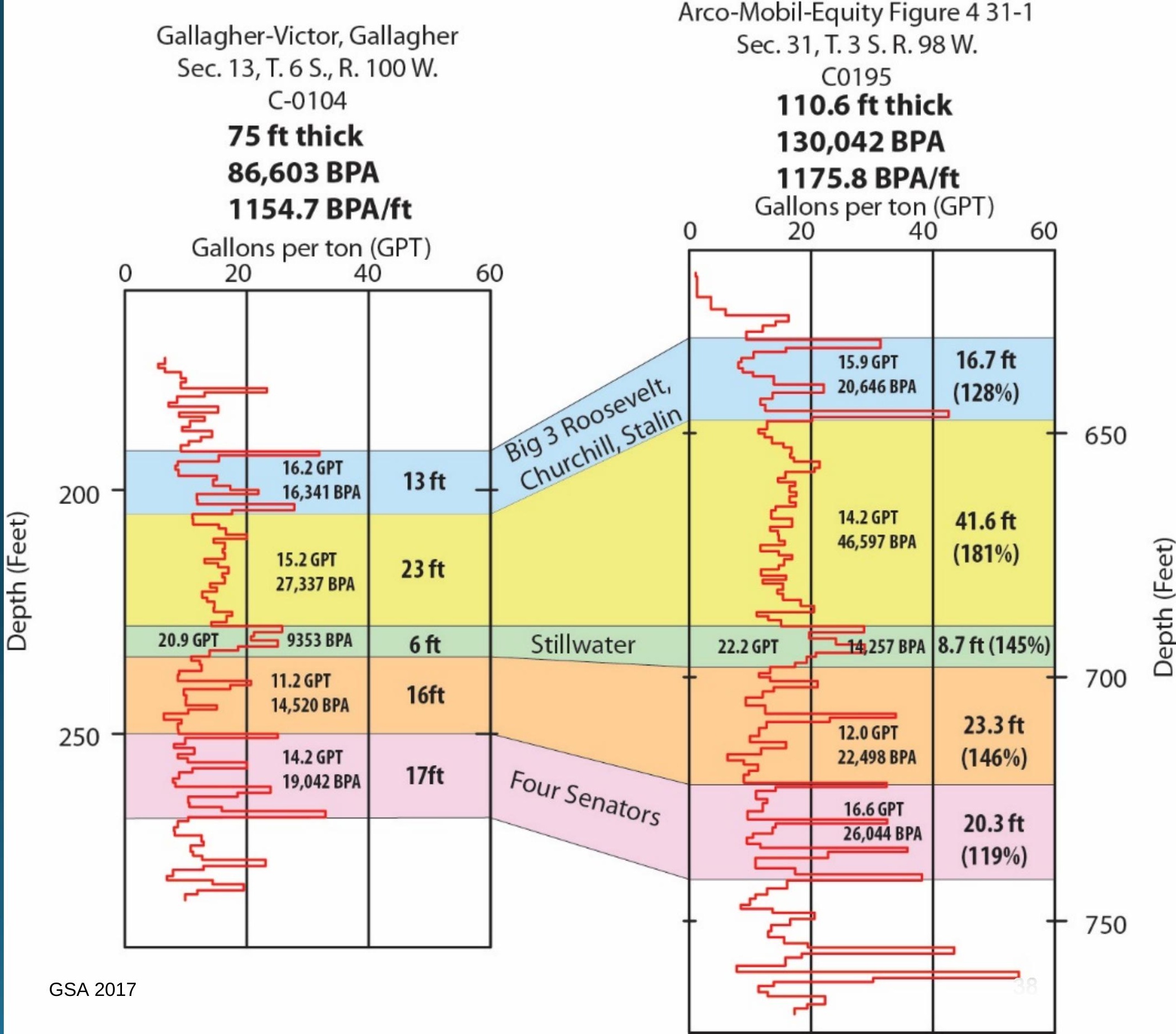


Thickness vs BPA trends for the five intervals in the two coreholes. Note the two scales for BPA and thickness one for the total bed 44 interval and the other for the subdivisions within the overall interval. Colors for each zone are same as previous slide

Four of the five subdivisions fall within or close to the trend for the entire bed 44 interval.

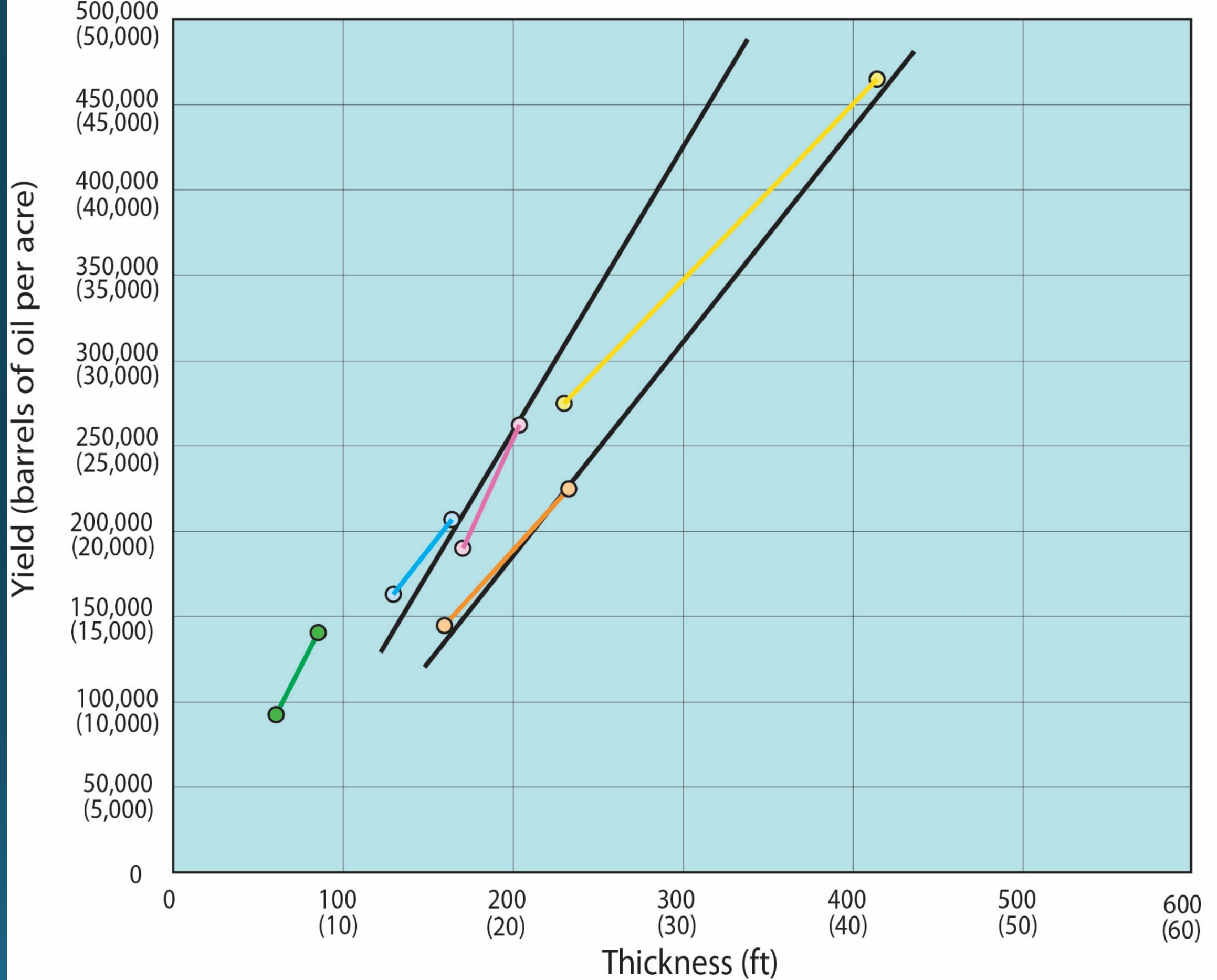


This published cross section is hung on the Long Point Bed. Next we will present a similar cross section that attempts to reconstruct the topography of Lake Uinta at the end of the bed 44 interval.

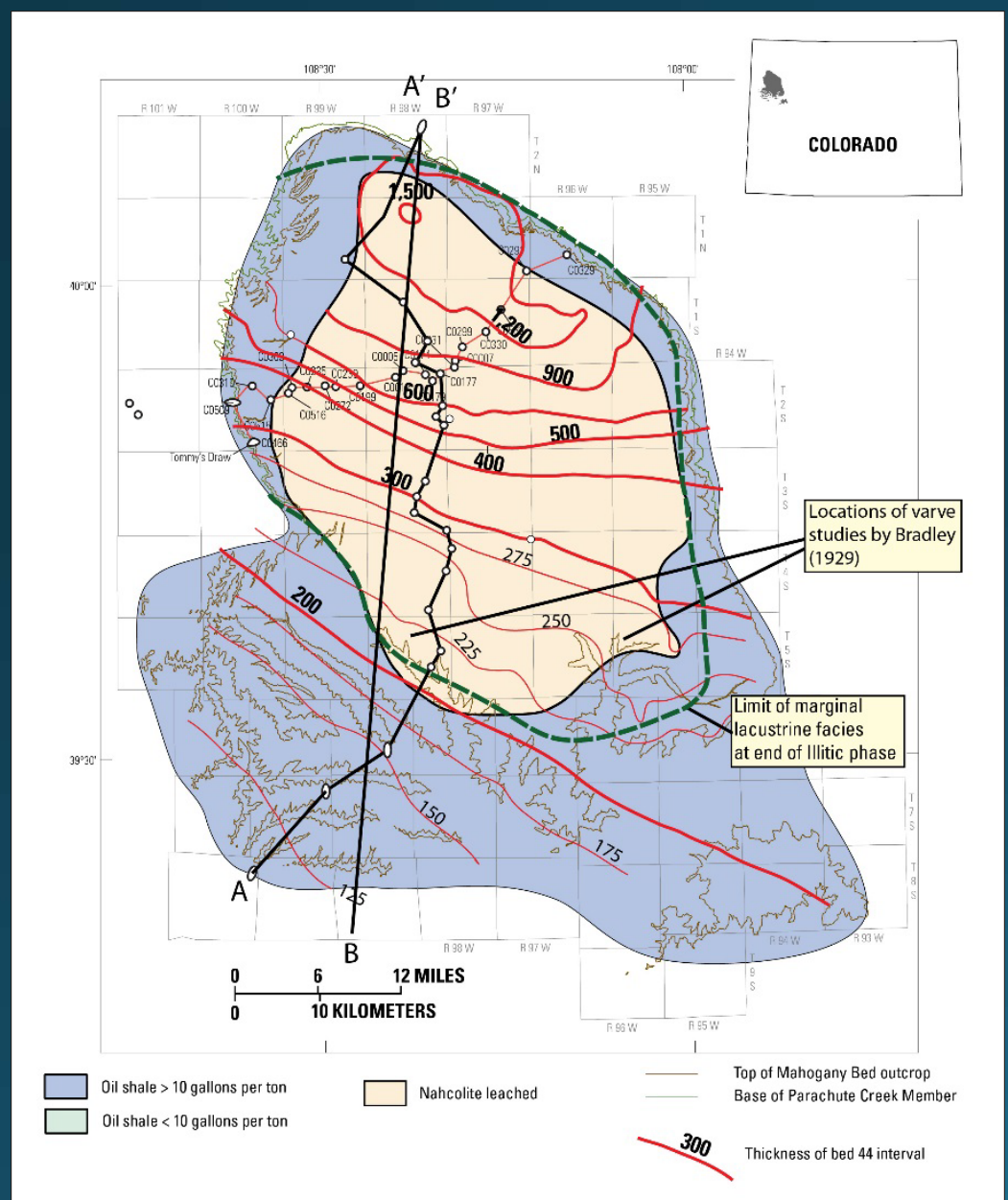

Modified from Johnson and Brownfield (2013)

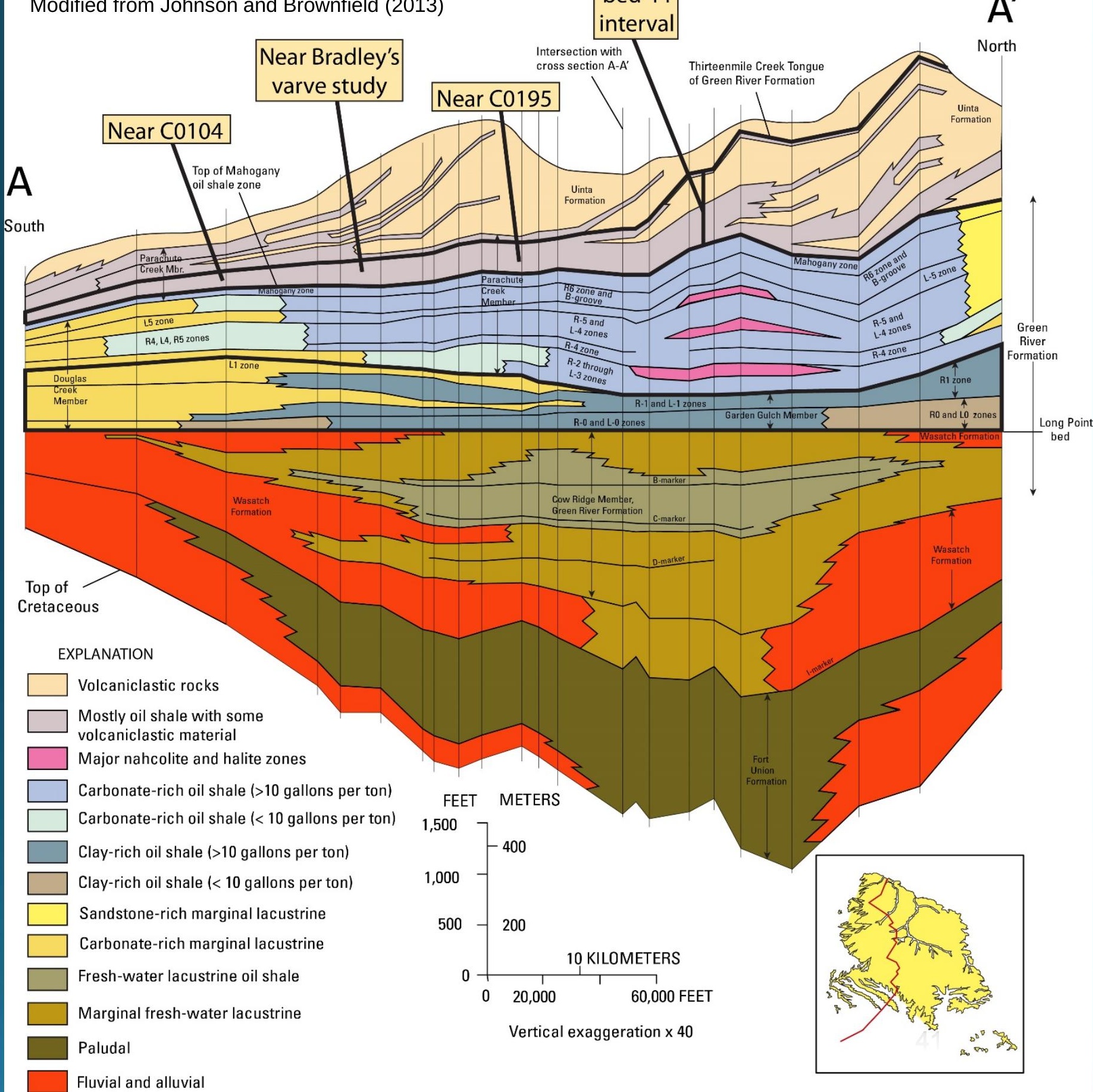




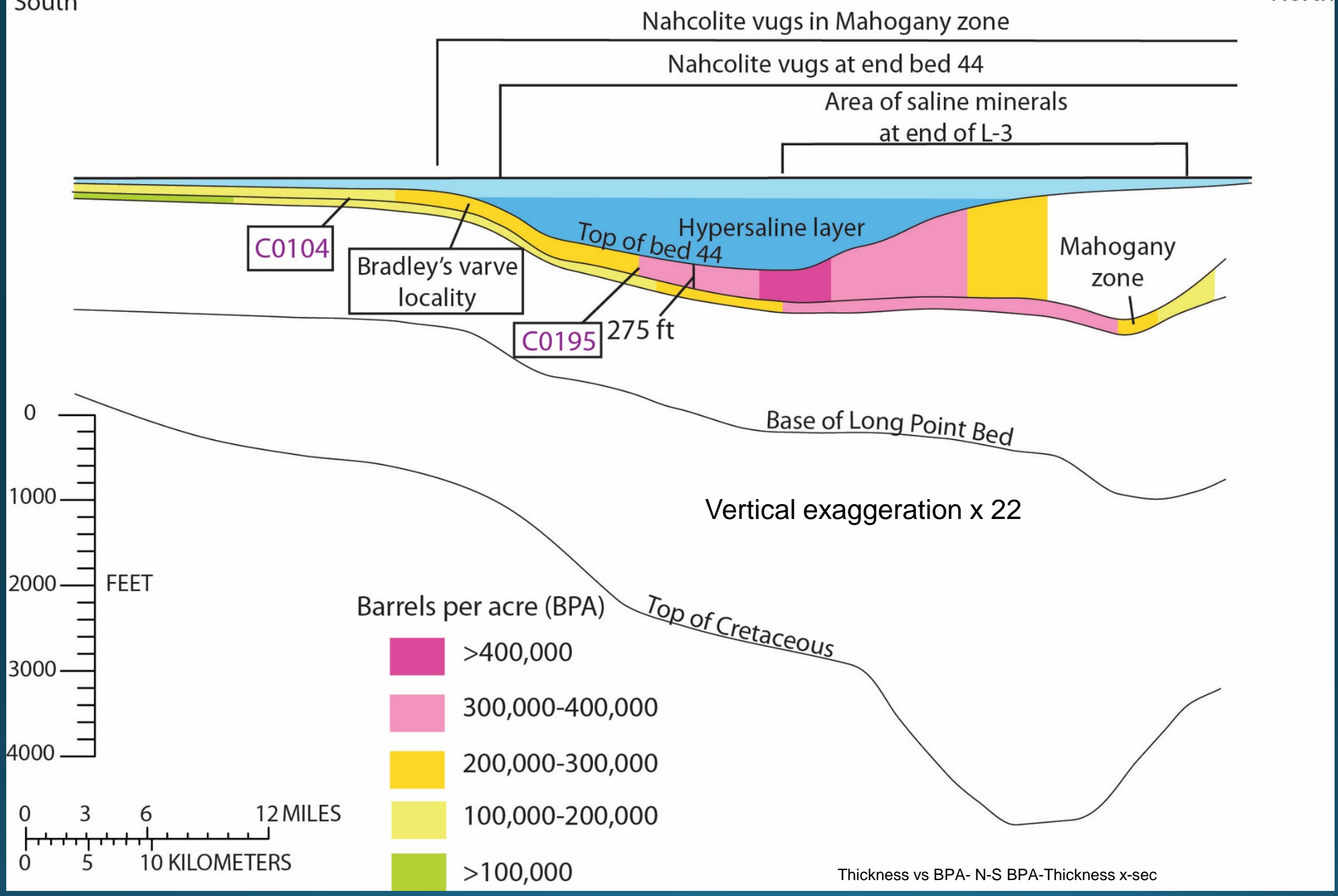

End of bed 44 showing: (1) barrels per acre, (2) hypersaline and upper less saline layers, (3) areas of saline mineral deposition for various time periods, and (4) hypothesized lake bottom topography. The hypersaline lower layer is shown to extend as far margin-ward as nahcolite vugs in the bed 44 interval. 


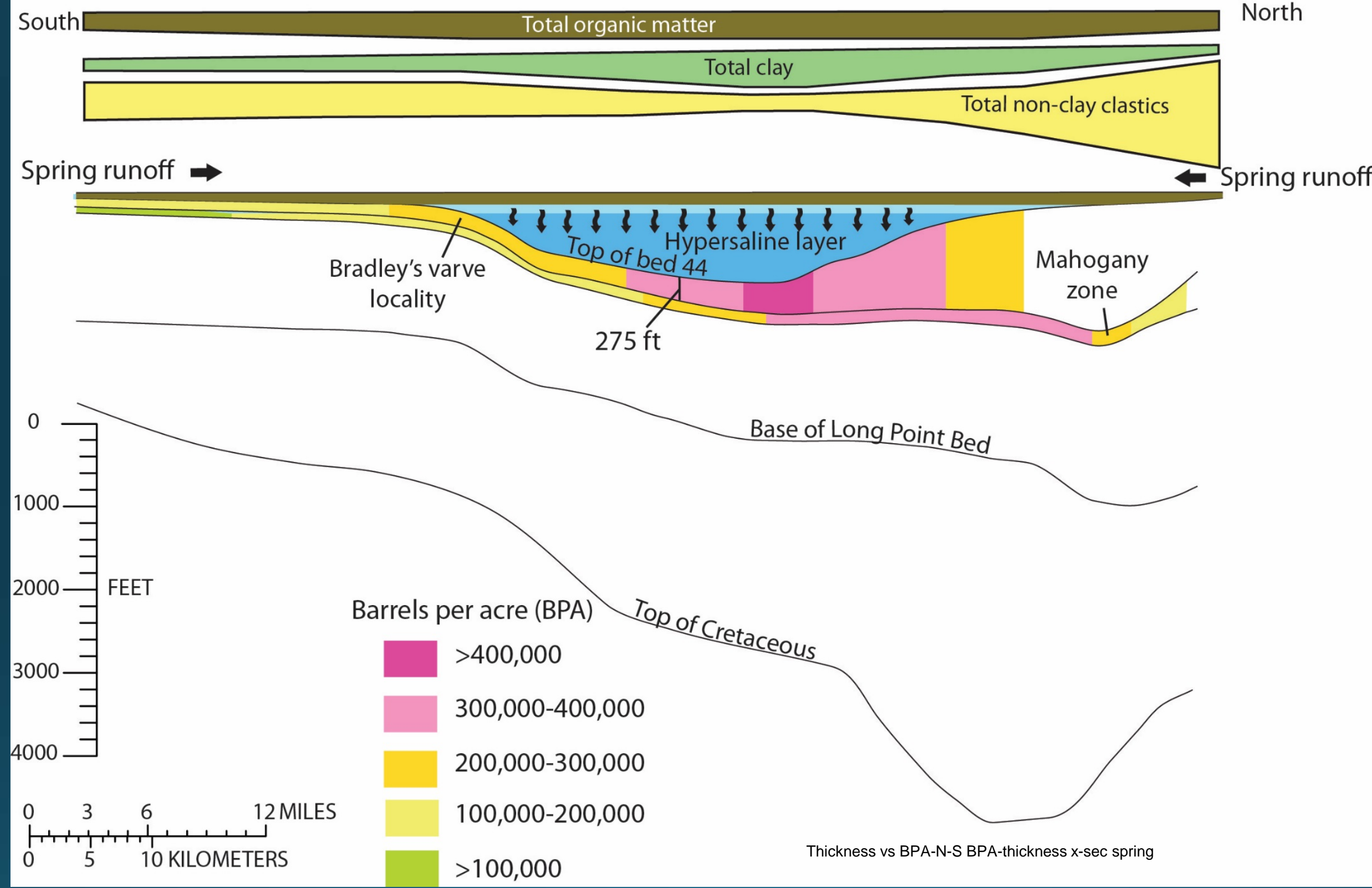

During spring floods, muddy water entered the lake and was circulated in the upper less saline layer across the entire extent of the lake. Clay particles picked up organic matter in the water column and fell to the bottom of the lake. Total clay and total preserved organic matter increased toward the center of the lake. 


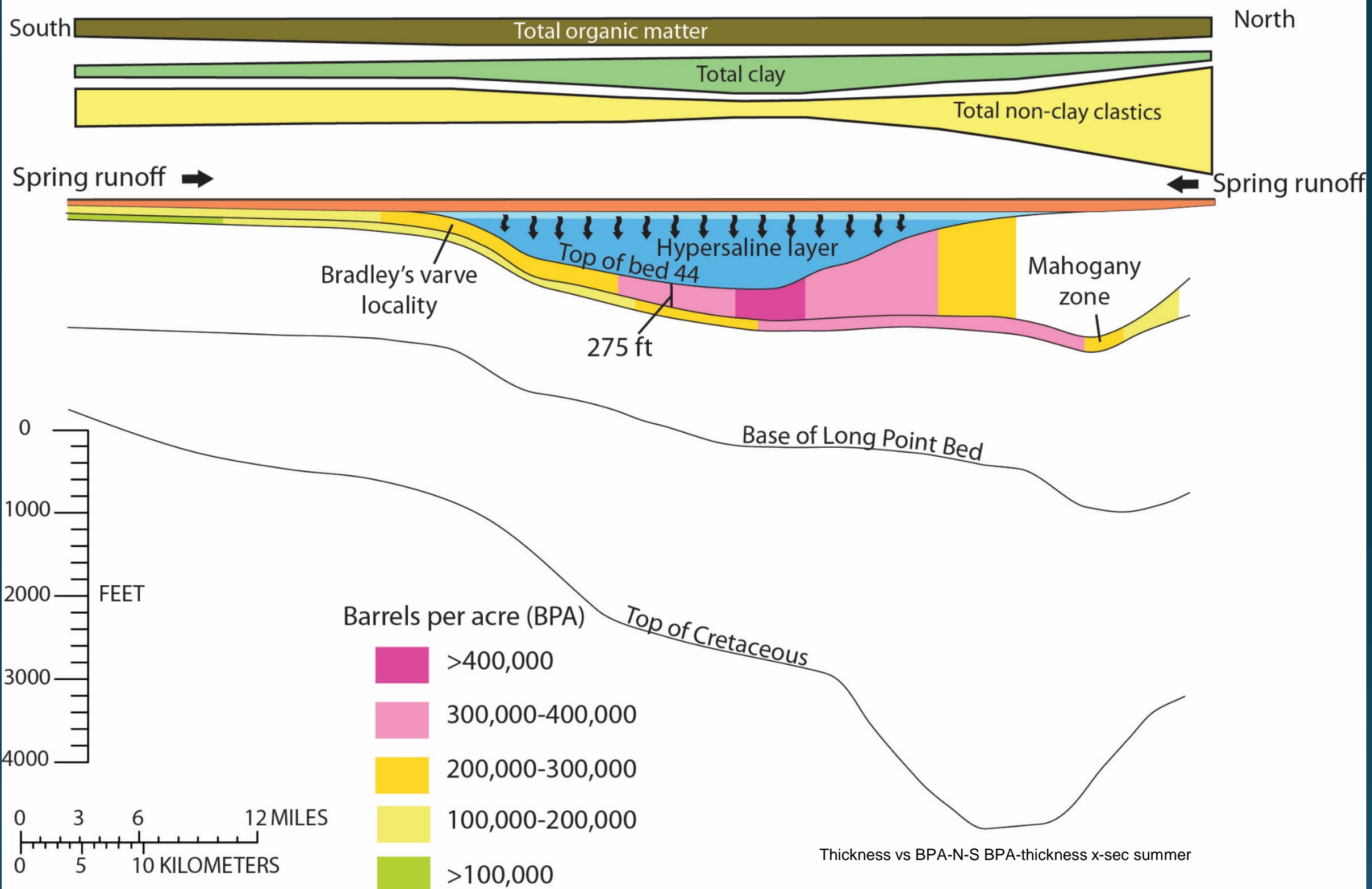

During the summer, carbonate precipitated out of the water column uniformly (?) across the lake and drops to the bottom. 
In the Black Sea, surface currents are highly variable, but in the deepwater areas, isolated cyclonic currents and the morphology of the basin control the distribution of sediments and organic matter (Shimkus and Trimonis (1974)
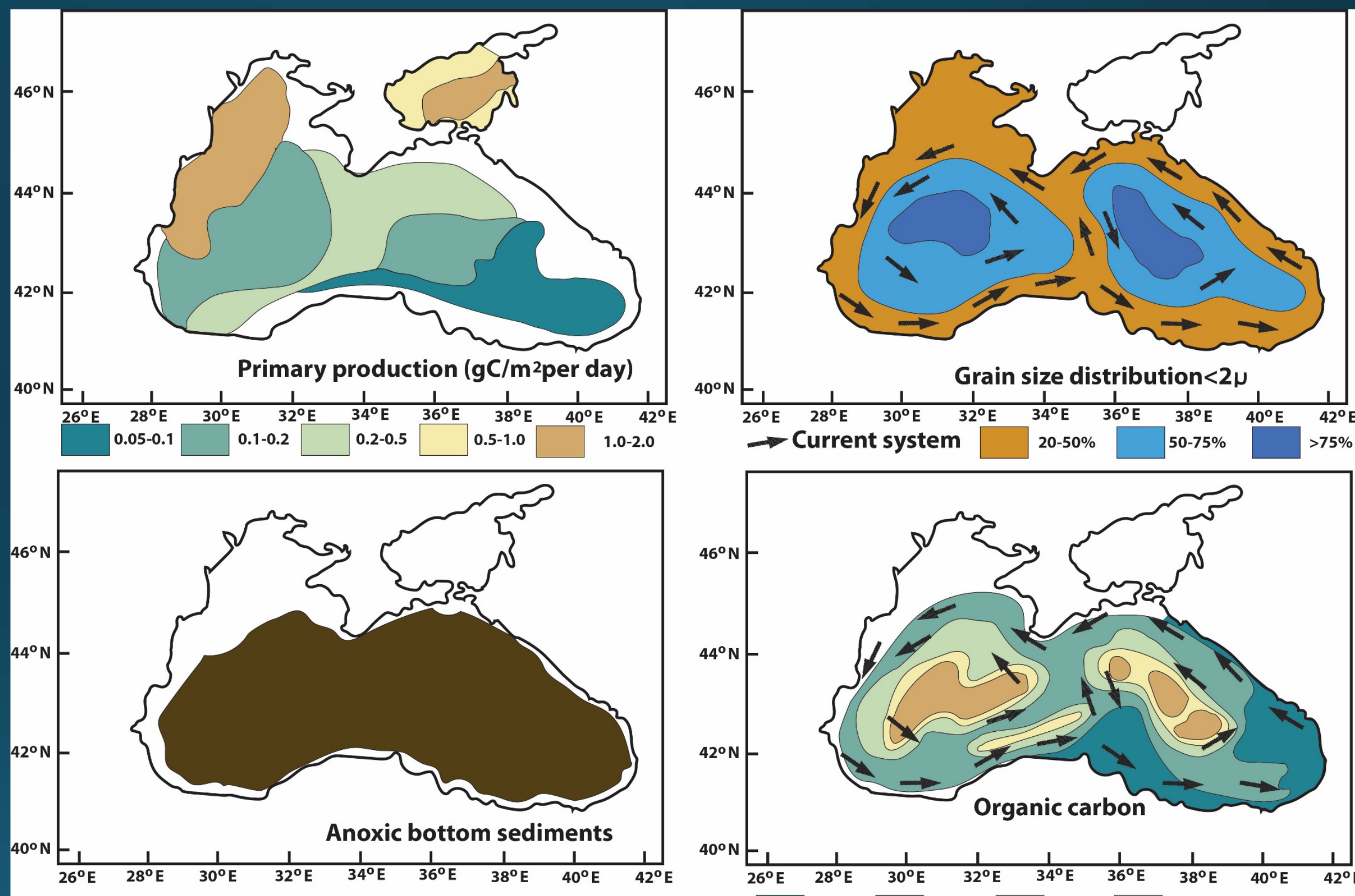

0

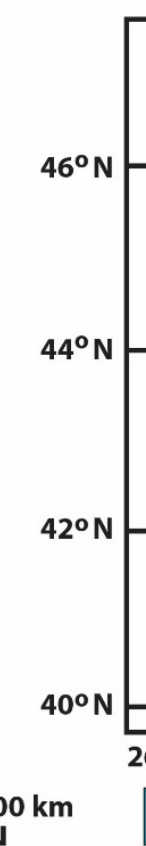

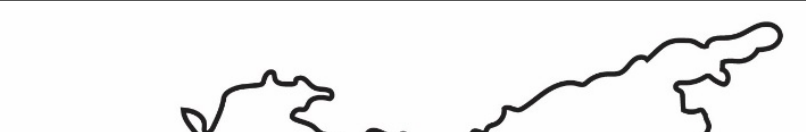
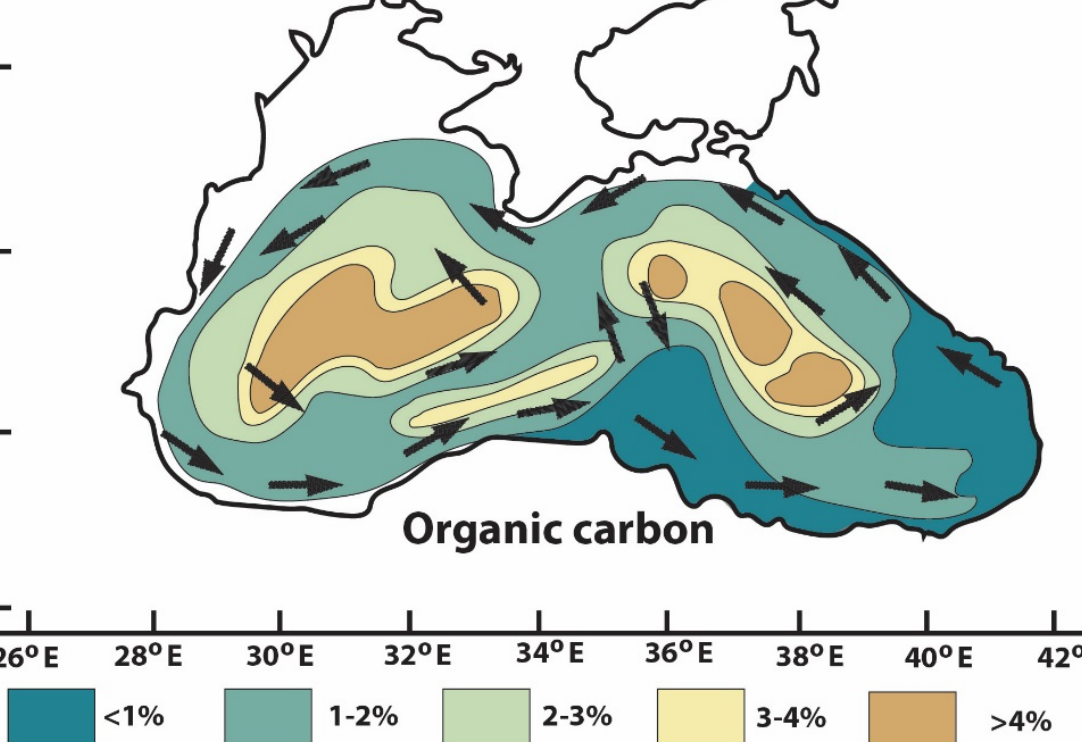
We propose that similar cyclonic currents with the Douglas Creek arch acting as a shallow sill could explain the distribution of organic matter in Lake Uinta.

Much of the organic matter in the deep Uinta Basin, however, has generated and expelled hydrocarbons.

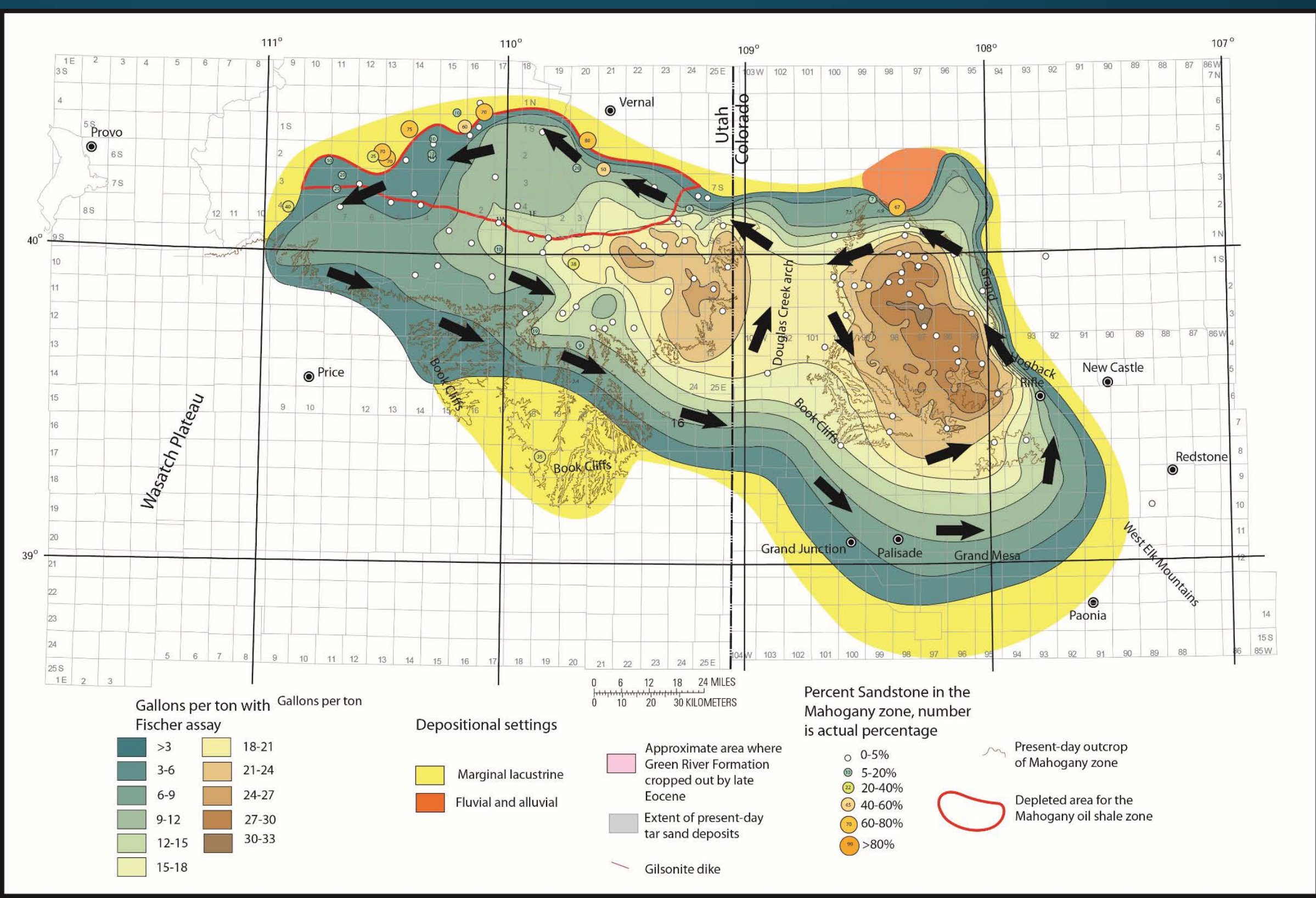


Total organic carbon in the Caspian Sea is closely related to water depth.

Total organic matter in Lake Uinta may also have been related to water depth. As currents homogenized organic matter and mineral matter in the water column, more of both would drop out of the water column where the water is deepest.
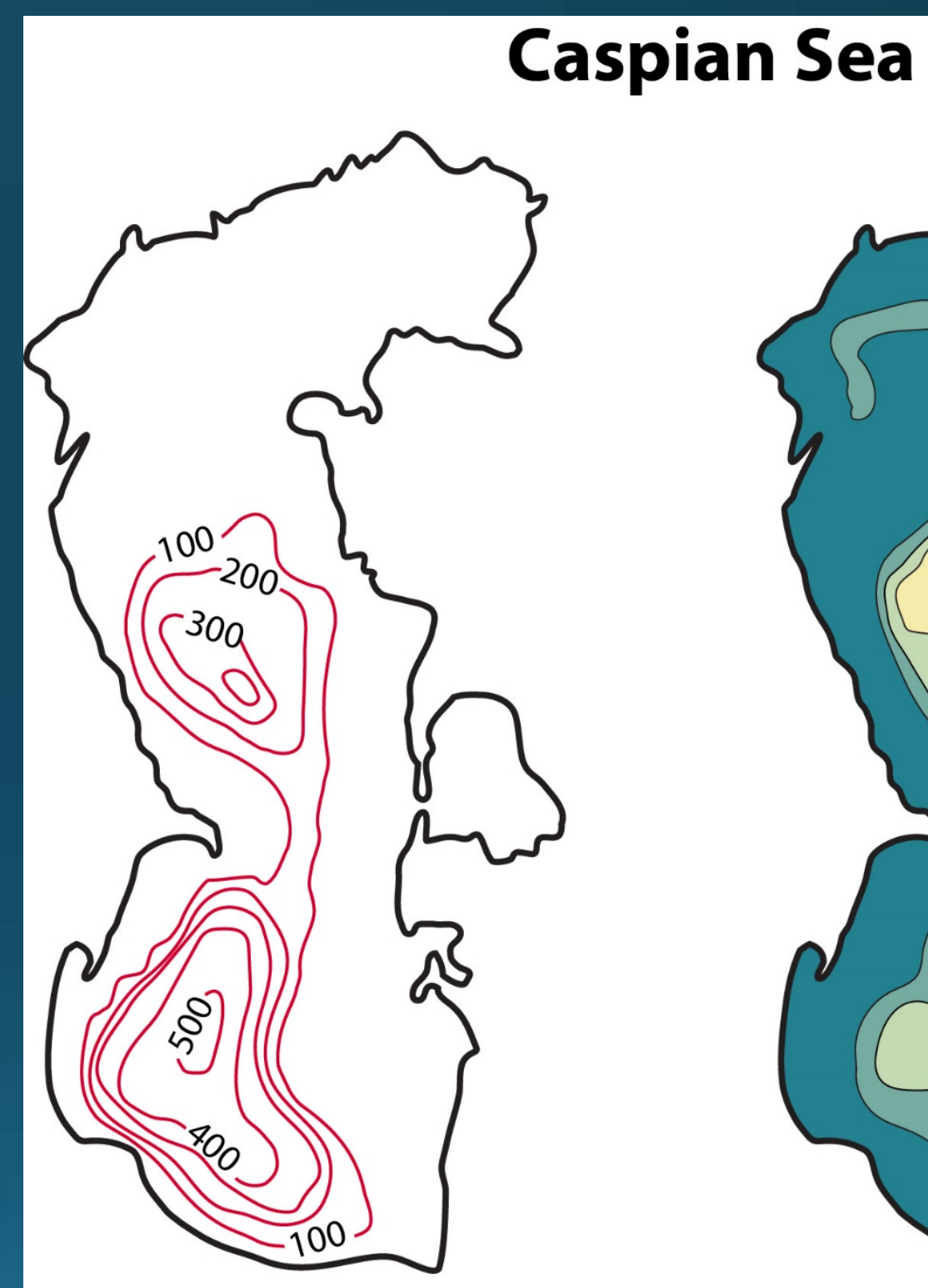

Water Depth

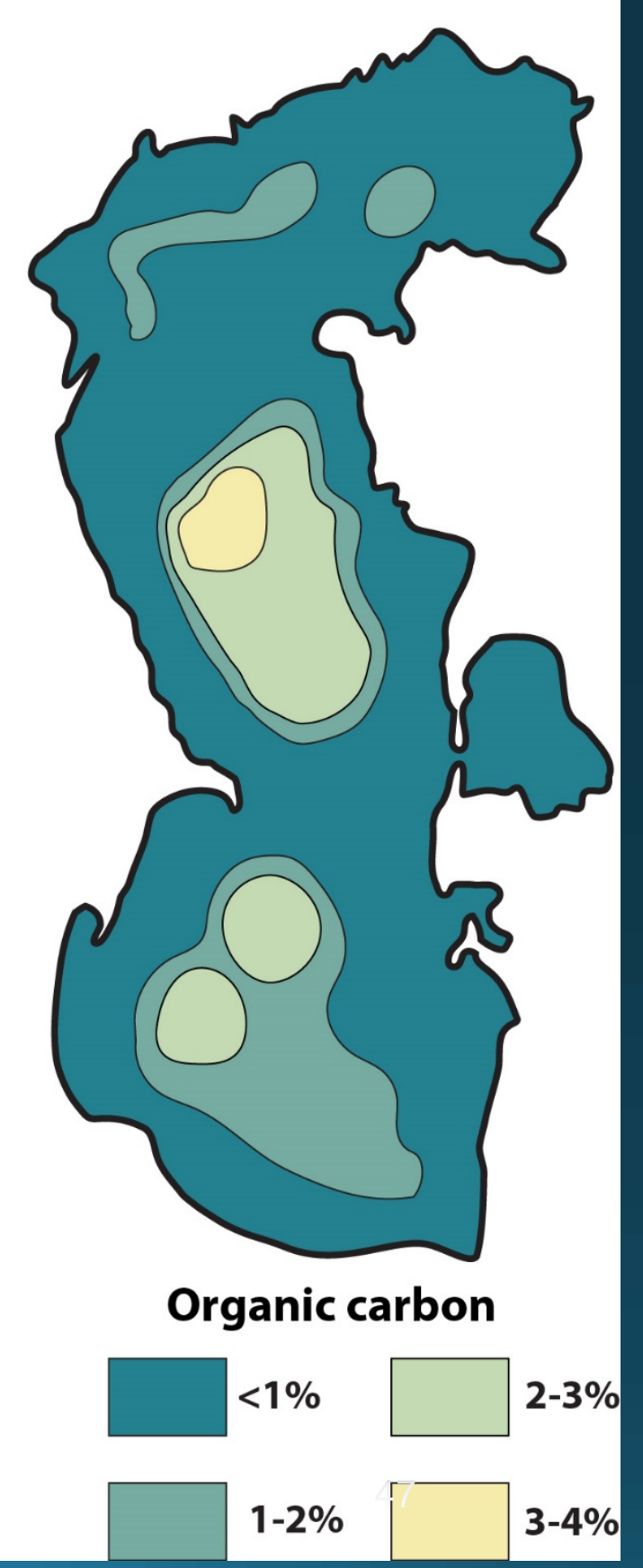




\section{CONCLUSIONS}

- We propose that in Lake Uinta most of the organic matter deposited in laminated intervals was captured by clay particles brought into the lake during spring floods with the organic-rich clay particles subsequently settling through the lower an denser highly alkaline, hypersaline layer to the bottom of the lake.

- Slow deep circulation similar to that found in present day inland seas such as the Black Sea might explain the distribution of organic matter in Lake Uinta with the percentage of clay and organic matter increasing toward the deepest parts of the lake. 
Thank You

\section{ZUSES}




\section{References Cited}

- Boak, Jeremy, Poole, Sheven, Feng, Jufang, 2016, Geochemistry of the Green River Formation, Piceance Creek Basin, Colorado: in Dolan, M.P., Higley, D.K., and Lillis, P.G., eds., Hydrocarbon Source Rocks in Unconventional Plays, Rocky Mountain Region, The Rocky Mountain Association of Geologists, p. 295-318.

- Bradley, W.H., 1929, The varves and climate of the Green River epoch: Shorter Contributions to General Geology, 1929, U.S. Geological Survey Professional Paper 158, p. 87-110.

- Bradley, W.H., 1963, Eocene Green River Formation, in D.G. Frey, ed., Paleoliminology, Limnology in North America: Madison, University of Wisconsin Press, p. 621-652.

- Bradley, W.H., and Eugster, H.P., 1969, Geochemistry and paleolimnology of the trona deposits and associated authigenic minerals of the Green River Formation of Wyoming: U.S. Geological Survey Professional Paper 496-B, 71 p.

- Cashion, W.B. and Donnell, J.R. (1972) Chart showing correlation of selected key units in the organic-rich sequence of the Green River Formation, Piceance Creek Basin, Colorado, and Uinta Basin, Utah. US Geol. Surv. Oil and Gas Investigations, Chart OC-65.

- Dyni, J.R., and Hawkins, J.E., 1981, Lacustrine turbidites in the Green River Formation, northwestern Colorado: Geology, v. 9, p. 235-238. 


\section{References Cited}

- Hedges, J.I., and Keil, R.G., 1995, Sedimentary organic matter preservation: an assessment and speculative synthesis: Marine Chemistry 49, 81-115).

- Huc, A.Y., Aspects of depositional processes of organic matter in sedimentary basins: Organic Geochemistry, Vol. 13, Nos., 1-3, p. 261-272.

- Johnson, R.C., 1985, Early Cenozoic history of the Uinta and Piceance Creek basins, Utah and Colorado, with special reference to the development of Eocene Lake Uinta, in Flores, R.M., and Kaplan, S.S., eds, Cenozoic Paleogeography of the West-Central United States, Rocky Mountain Paleography Symposium 3: The Rocky Mountain Section, Society of Economic Paleontologists and Mineralogists p. 247-276.

- Johnson, R.C., 1989, Detailed cross section correlating the Upper Cretaceous and lower Tertiary rocks between the Uinta basin of eastern Utah and western Colorado and the Piceance basin of western Colorado: U.S. Geological Survey Miscellaneous Investigations Map 1-1974, 2 large sheets.

- Johnson, R.C., 2014, Detailed north-south cross section showing environments of deposition, organic richness, and thermal maturities of Lower Tertiary rocks in the Uinta Basin, Utah: U.S. Geological Survey Digital Data Series map, U.S. Geoligical Survey Scientific Investigations Nao 3304, 12 p. and 1 plate

http://pubs.usgs.gov/sim/3304/pdf/sim3304

- Johnson, R.C., Mercier, T.J., Brownfield, M.E., Pantea, M.P., and Self, J.G., 2010, An assessment of in-place oil shale resources of the Green River Formation, Piceance Basin, Colorado: Oil Shale and Nahcolite Resources of the Piceance Basin, Colorado, U.S. Geological Survey Digital Data Series DDS-69-Y, Chapter 1, 187 p. 


\section{References Cited}

- Johnson, R.C. and Brownfield, M.E., 2013, Development, evolution and destruction of the saline mineral area of Eocene Lake Uinta, Piceance Basin, western Colorado: U.S. Geological Survey Scientific Investigations Report 2013-5176. https://pubs.usgs.gov/sir/2013/5176/downloads/plate 02.pdf

- Johnson, R.C., and Brownfield, M.E., 2015, Development, evolution, and destruction of the saline mineral area of Eocene Lake Úinta, Piceance Basin, western Colorado: U.S. Geological Survey Scientific Investigations Report 2013-5176, 75 p. and two oversized plates http://dx.doi.org/10.3133/sir20135176.

- Johnson, R.C., Birdwell, J.E., and Mercier, T.J., 2016, Generation and Migration of Bitumen and Oil from the Oil Shale Interval of the Eocene Green River Formation, Uinta Basin, Utah: in Dolan, M.P., Higley, D.K., and Lillis, P.G., Hydrocarbon Source Rocks in Unconventional Plays, Rocky Mountain Region: Rocky Mountain Association of Geologists, p. 379-420.

- Johnson, R.C, Birdwell, J.E., and Mercier T.J., 2017, Mineral occurrence data for the Eocene Green River Formation in the Piceance and Uinta Basins: U.S. Geological Survey Data Release DOl: 10.5066/F7XP7334

- Keil, R.G., and Hedges, J.I., 1993, Sorption of organic matter to mineral surfaces and the preservation of organic matter in coastal marine sediments Chemical Geology, 107, 385388). 


\section{References Cited}

- Kennedy, M.J., Pevear, D.R., and Hill, R.J., 2002, Mineral surface control of organic carbon in Black Shale: Science $25,657-660$.

- Ludlam, S.D., 1969, Fayetteville Green Lake, New York. 3. The laminated sediments: Limnology and Oceanography, 14, p. 848-857.

- Pakomova, A.C., 1969, Organic carbon in recent sediments from the Caspian Sea: in O.K. Bordovskiy, ed., Organic Matter of Recent Sediments of the Caspian Sea, Oceanology 9, p. 799-807.

- Poole, Sheven, 2014, Quantitative mineralogy and distributions of minerals of the Green River Formation, Piceance Creek Basin, western Colorado: MSc Thesis, Colorado School of Mines, Golden, Colorado.

- Salmon, V., Derenne, S., Lallier-Verges, E., Largeau, C., and Beaudoin, B., 2000, Protection of organic matter by mineral matrix in a Cenomanian black shale, Organic Geochemistry 31, 463-474.

- Shimkus, K.M., and Trimonis, E.S., 1974, Modern sedimentation in Black Sea, in E.T. Degens, and D.A. Ross, eds., The Black Sea, Geology, Chemistry, and Biology, American Association of Petroleum Geologists Memoir 20, p. 249-278.

- Washburn, K.E., Birdwell, J.E., Foster, Michael, and Gutierrez, Fernando, 2015, Detailed description of oil shale organic and mineralogical heterogeneity via Fourier Transform Infrared Microscopy: Energy and Fuels. V. 29. p. $4264-4271$. 
- Mineral occurrence maps were generated using recently released USGS data release:

Map generated using "Mineral Occurrence data for the Eocene Green River Formation in the Piceance and Uinta Basins", https://doi.org/10.5066/F7XP7334

- The database includes 9443 analyses from 30 cores in the Piceance Basin and 1200 samples from 14 cores in the Uinta Basin. We did not try to quantify mineral percentages 